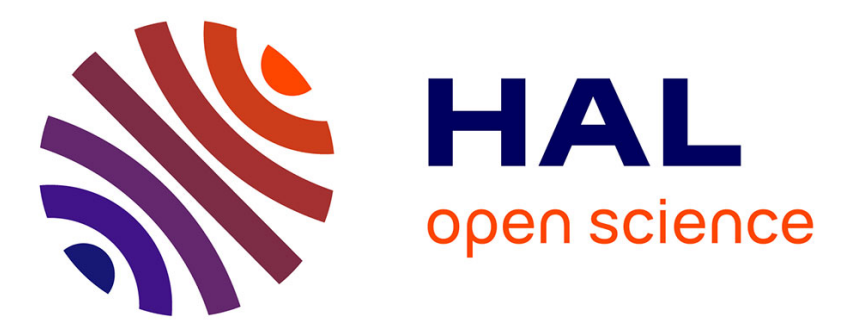

\title{
Towards a better understanding of eating behaviour through the concept of Perception of Nutritional Risk
}

Marie-Eve Laporte, Géraldine Michel, Sophie Rieunier

\section{To cite this version:}

Marie-Eve Laporte, Géraldine Michel, Sophie Rieunier. Towards a better understanding of eating behaviour through the concept of Perception of Nutritional Risk. Recherche et Applications en Marketing (English Edition), 2017, 30 (1), pp.76-109. 10.1177/2051570714564532 . halshs-02923251

\section{HAL Id: halshs-02923251 \\ https://shs.hal.science/halshs-02923251}

Submitted on 26 Aug 2020

HAL is a multi-disciplinary open access archive for the deposit and dissemination of scientific research documents, whether they are published or not. The documents may come from teaching and research institutions in France or abroad, or from public or private research centers.
L'archive ouverte pluridisciplinaire HAL, est destinée au dépôt et à la diffusion de documents scientifiques de niveau recherche, publiés ou non, émanant des établissements d'enseignement et de recherche français ou étrangers, des laboratoires publics ou privés. 
Article RAM

\title{
Toward a better understanding of eating- behaviour through the concept of Perception of Nutritional Risk
}

\author{
Marie-Eve Laporte ${ }^{1}$ \\ Laboratoire GREGOR, IAE Paris I Panthéon Sorbonne, France \\ Géraldine Michel \\ Laboratoire GREGOR, IAE Paris I Panthéon Sorbonne, France
}

\section{Sophie Rieunier}

Laboratoire GREGOR, IAE Paris I Panthéon Sorbonne, France

\begin{abstract}
The general public's nutritional behaviour is a priority of public-health authorities. Associated diseases are the prime cause of mortality worldwide. For reasons of public health, a better understanding of the consumer Perception of Nutritional Risk (PNR) is essential, since this, according to the protection motivation theory, influences behavioural intention (Maddux and Rogers, 1983; Rogers, 1975). Following a review of the literature and qualitative research, the present article endeavours to clarify the concept of PNR, explore potential explanatory or moderating factors, and identify leads for future research. We show that PNR depends not solely on the product characteristics (role of perceived naturalness), but also the consumption situation (role of commensality) and purchasing conditions (role of hyperchoice).
\end{abstract}

\section{Key words}

Food, nutrition claims, commensality, consumer behaviour, hyperchoice, naturalness, nutritional risk

\section{Introduction}

"Nutritional diseases" are defined by the FAO (Food and Agriculture Organization of the United Nations) as cardio-vascular diseases, obesity, diabetes, and certain cancers (Latham, 2001). Given the increasing cost in both human and economic terms of chronic nutritional diseases - behind some $60 \%$ of deaths worldwide (WHO and FAO, 2003) - this is a priority for public-health authorities. Wrongly called "diseases of the rich", nutritional diseases are increasing at an alarming rate in developing countries, and mainly affecting the poorer members of industrialised countries (Latham, 2001; WHO and FAO, 2003). Further, the agrifood industry is accused of directly contributing to their spread, obesity being the most obvious case in point (Brée, 2010; Moore and Rideout, 2007). In response to the criticism, and following in Danone's footsteps and their pioneering 1987 "Bio"

${ }^{1}$ Corresponding author:

Marie-Eve Laporte, Laboratoire GREGOR, IAE Paris I Panthéon Sorbonne, 21 rue Broca, Paris Cedex 05, 75240, France Email: marie-eve.laporte@orange.fr 
yoghurt (now Activia), numerous brands have stepped up the use of nutrition claims ${ }^{1}$, despite subsequent restrictions on their use by European regulation no. 1924/2006. With today's consumer better informed than before, one might have expected an improvement in eating-behaviour, but this is not the case. According to some obesity researchers (Nestle, 2007; Wansink and Chandon, 2006), nutrition claims may even have an opposite effect on people's health, for example, causing much larger quantities to be consumed when the product is stated as "low-cal".

Central to this paradox is the concept of consumer Perception of Nutritional Risk (PNR). Nutritional risk is a long-term component of food risk (Aurier and Sirieix, 2009) and reveals itself via the side effects of foodstuffs ingested (Ferreira, 2006) - for example, deficiencies or unexpected weight gain or loss - on health, the latter being defined as "... a state of complete physical, mental and social well-being..." (WHO, 1946). Various papers (Moon and Balasubramanian, 2003; Pennings et al., 2002) have demonstrated the value of differentiating the "perception of risk" from "attitude toward risk" in shedding light on the behaviour of individuals facing food risk. Perception of risk is thus how consumers interpret their exposure to risk, and attitude toward risk is their general predisposition to take this type of risk (Pennings et al., 2002). Research on attitude toward risk tries to explain why consumers take nutritional risk, differentiating for example those individuals seeking well-being - i.e. geared towards health promotion - from those seeking to avoid disease - i.e. geared towards disease prevention - (Gomez, 2009b; Gurviez, 2010; Werle et al., 2012). However, none of these papers uses PNR.

And yet changing behaviour requires changing the perception of risk. According to Rogers' protection motivation theory, both probability of occurrence (vulnerability) and severity of threat are premises to the intention to protect oneself (Maddux and Rogers, 1983; Rogers, 1975), and are the two facets of perceived risk (Bauer, 1960) illustrated in Fig. 1.

[Figure 1]

So PNR would thus appear to be an antecedent of behavioural intention, an "indications of how hard people are willing to try, of how much of an effort they are planning to exert, in order to perform the behavior" (Ajzen, 1991). And behaviour results from behavioural intention, not only in Rogers' model, but also in the theory of reasoned action (Ajzen and Fishbein, 1980; Fishbein and Ajzen, 1975) or in the theory of planned behaviour deriving from it (Ajzen, 1991). Consequently, with the objective of improving human eating-behaviour and, more particularly, of limiting deficiencies and regulating calorie intake, it seems useful to understand PNR and its mechanisms: how do consumers assess their exposure to the nutritional risk of products they consume? Which factors influence their PNR?

To answer these questions, the present paper will start by reviewing the research on the Perception of Nutritional Risk, following up by a qualitative study on 18 consumers. It will then put the results into perspective, suggest possible research and present its limitations. From the academic point of view, it will clarify PNR and suggest a link with three marketing-related concepts, each one in a different category: among product-related variables, perceived naturalness; among those related to the consumption situation, commensality; and among those related to the purchasing environment, hyperchoice. Lastly, from a social management perspective, the paper alerts publichealth authorities to the mechanisms underlying PNR, with a view on improving people's nutritional behaviour.

\section{Perception of Nutritional Risk by the consumer}

Perception of Nutritional Risk is a concept recent enough to be still little used in marketing literature. To understand it better involved exploring related fields of research such as the sociology and psychology of food, economics, the psychology and sociology of risk, agri-food marketing, and nutrition. 


\section{The anxiety of eating}

Food is not a consumer good like the rest (Poulain, 2002). Alongside its hedonistic and social character, eating contains a grain of biological risk inherent to the vital (i.e. life-essential) and multidaily ingestion of food (Kapferer, 1998; Rozin, 2005a). It is also based upon the "principle of incorporation" (Fischler, 1990), contributing to a construction of self-identity from childhood on (Gurviez, 2001), transforming the individual from within. While humans assimilate the nutrients contained in food, they also do with the representations they make of it (Fischler, 1990) through "magic thoughts" (Frazer, 1911). Hence, each society creates its own references of what is edible and what is not (Merdji, 2006). Lastly, humans are also faced with an insurmountable contradiction, the "paradoxe de l'homnivore" (untranslatable pun, the silent $h$ of homme, French for man, implying humans as conscious omnivores) (Fischler, 1990, 2001). Man must be neophobic to protect himself from food that could make him ill, or even kill him, but also be neophilic to ensure the nutritional diversity needed to stay healthy. All of these characteristics specific to food consumption highlight its potential to generate anxiety, even if pleasure and social intercourse are still essential to representations of food in France, described by one French writer as the "Law of two Ss": "SécuritéSanté" as concerns English-speaking countries (safety and health), and "Saveur-Sociabilité" (flavour and sociability) elsewhere (Ferrières, 2006).

\section{Nutritional risk}

Risk is a complex concept, first of all due to its twofold character, both objective and subjective (Douglas and Wildavsky, 1983; Kahneman and Tversky, 1979; Rosa, 2003). It is "in part an objective threat of harm to people and in part a product of culture and social experience" (Kasperson, in Pidgeon et al., 2003). Another difficulty lies in the multidimensional character of the risk perceived (Mitchell, 1999; Volle, 1995), related as much to aspects be they physical, psychological, social, financial, performance-oriented (Cox, 1967; Kaplan et al., 1974), as time-wasting (Cox, 1967; Roselius, 1971) or ethical (Aurier and Sirieix, 2009; Douglas and Wildavsky, 1983; Kermisch, 2011; Kytle and Ruggie, 2005; Méric et al., 2009). Given the vital nature of food, it is the physical aspect which prevails in food risk (Aurier and Sirieix, 2009; Bergadaà and Urien, 2006; Gallen, 2001) which in turn is broken down into the short-term health risk of poisoning - by food contamination - and the long-term nutritional risk of side effects (Aurier and Sirieix, 2009; Ferreira, 2006) as illustrated in Table 1. As to PNR, this expresses long-term "uncertainty due to making the wrong choice" of food (Aurier and Sirieix, 2009) on one's physical, mental and social health.

[Table 1]

Nutritional risk is caused by imbalances, deficiencies or excesses, such as repeated exposure to ingredients which, cumulatively, may end up harmful, either alone or in combination with others through a "cocktail effect" (Chevallier, 2009). It can even result in nutritional diseases affecting the individual's longevity or quality of life. However, the consequences are not just physical, they affect the individual's psychological well-being and social identity too, and thus include a psychosocial aspect (Bergadaà and Urien, 2006). Whereas society deals with health risk as a whole, it leaves nutritional risk up to the individual, assumed responsible for his own nutritional choices (Fischler, 1990; Fischler and Masson, 2008; Lipovetsky, 2006).

Be this as it may, not all individuals have the same attitude to nutritional risk: women, for example (particularly mothers), the elderly and the sick all pay more attention to food (Fischler et al., 2010; Grunert and Wills, 2007; Zingg et al., 2013), women because they are responsible for others, and the elderly due to a distorted perception of time (Bech-Larsen and Scholderer, 2007). Teenagers, on the other hand, tend more to be risk-seeking (Camous, 2011), this possibly representing a rite of passage towards adulthood (Lardellier, 2011). For them, the consequences are too far-removed to be 
of much concern (Werle et al., 2012). So, both individual attitude to nutritional risk and PNR must be taken into account in explaining the taking of nutritional risk. According to the protection motivation theory shown in Fig. 1, consumers much first perceive a nutritional risk before adopting preventive behaviour (Maddux and Rogers, 1983; Rogers, 1975). But, although necessary, this condition is not enough: despite PNR, an individual will accept taking the risk depending on their own attitude toward risk (Pennings et al., 2002).

\section{The ambiguous influence of nutrition claims on PNR}

Because it's so difficult to evaluate the nutritional characteristics of food, consumers tend to use selection heuristics (Gomez, 2009a, 2009b; Larceneux, 2003b). These decision-making short-cuts allow them to simplify and speed up their decision-making process (Tversky and Kahneman, 1992). To do so, consumers may rely on indicators of quality intrinsic to the product, such as appearance (Brunel and Pichon, 2004; Sirieix, 1999), or extrinsic to the product, such as brand (Kapferer, 1998; Michel, 2004), labels (Larceneux, 2003a, 2003b) and, more and more often, nutrition claims (Gomez, 2008). On their packs, for example, LU Prince biscuits state "contains no colouring-agents, preservatives, hydrogenated fat; rich in cereals and milk". So how do nutrition claims influence eating-behaviour? Research reveals there are ambiguous effects at work. Needless to say, the results must be analysed in the light of where the research was done. There are considerable cultural differences in relation to nutritional risk between the United States, and northern and southern Europe (Fischler et al., 2010; Fischler and Masson, 2008; Grunert and Wills, 2007; Rozin et al., 2006). For example, food seems more individual and medical in the United States, and social and convivial in France due to its cultural heritage (Fischler and Masson, 2008).

Various experiments conducted in the United States have revealed that the presence of nutrition claims leads to an increase in weight of which the consumer is unaware (Chandon and Wansink, 2010). Consumers pigeonhole food according to the rather black or white criterion as to whether it's either good or bad for your health, irrespective of amount (Chernev and Gal, 2010). One experiment, for example, showed that when faced with "lo-fat" M\&Ms, consumers increased the size of their portions and energetic intake (Wansink and Chandon, 2006). So the presence of nutrition claims seems to inhibit PNR. And the phenomenon is amplified in the overweight (Wansink and Chandon, 2006), leading some researchers to draw parallels between the agrifood and tobacco industries (Nestle, 2007): since "low-tar" (or similar) cigarettes were assumed to reduce addiction and risks, smokers felt less guilty and smoked more, inhaling even more deeply, with the risk of developing cancers lower in the lungs (Brownell and Warner, 2009). Alongside this, low-calorie food intended to decrease energetic intake may also result in a greater absorption of calories (Nestle, 2007; Wansink and Chandon, 2006), even more so in people already overweight, due to increased portion size (Chandon and Wansink, 2007a).

In France, on the other hand, nutrition claims seem to increase PNR. The French, for example, will give a plain yoghurt a higher health score than a low-cal version or one enriched with an ingredient good for the health (Fischler et al., 2010). Likewise, artisanal or "home-farm" ham is thought healthier than varieties with reduced fat or fortified in omega 3 (Merdji, 2012). The cultural difference in attitude to nutrition claims could help explain this difference between the United States and France (Grunert and Wills, 2007). In both situations, however, nutrition claims do seem to affect PNR in one way or another.

\section{Consumer suspicion of nutrition claims}

Using nutrition claims as quality indicator presupposes that consumers trust the "quality conveyed" (Brunel and Pichon, 2004; Sirieix, 1999; Sirieix and Dubois, 1999). Research, however, reveals 
considerable consumer scepticism towards brands and their health claims (Gurviez, 2010; Keller et al., 1997). Since a good deal of nutrition has a belief-based component which consumers are incapable of verifying (Gomez, 2009b; Larceneux, 2003a, 2003b; Mason, 2009), nutrition claims are often perceived as little else but marketing speak (Burton and Creyer, 2004; Kozup et al., 2003). As such, they are not considered credible sources of nutritional information since neither of the two conditions - competence and integrity - are fulfilled (Simon et al., 1970). To start, "marketing" is not perceived as a nutritional expert due to "food cacophony" (IREMAS, 2010). Secondly, the increasingly informed consumer of today, aware of a conflict of interest between their own research into nutritional quality and the company's profit objectives, is leery of marketers (Singh and Sirdeshmukh, 2000). As a result, nutritional values given by public-health authorities are thought more credible than claims assumed to be brandspeak and hence little but promises, promises (Burton and Creyer, 2004; Kozup et al., 2003).

This consumer scepticism seems even greater in France due to the question mark over social representations of food and the "collective identity" (Gurviez, 2010), based on a shared historical and cultural footing (Ferrières, 2006; Fischler and Masson, 2008; Flandrin and Montanari, 1996). For example, a web ethnographic of negative comments on Danone's Actimel revealed consumer resistance to claims of its increasing immune defence ${ }^{2}$ for being incongruent with and a threat to the French eating model (Gurviez, 2010). From its anti-consumerist point of view, the anti-Actimel party attacked a "marketing coup" designed to enrich the company at the expense of the more vulnerable by means of guilt and emotional manipulation (Gurviez, 2010).

To conclude the review of the literature, Fig. 2 summarises the presumed relations between the variables in question. To shed light on consumer eating-behaviour and improve public health, a better understanding of PNR and its mechanisms seems essential. The following qualitative research will thus endeavour to identify other factors which may influence PNR or the relation between PNR and behavioural intention.

[Figure 2]

\section{Qualitative research}

The literature review has shown the complexity of PNR and ambiguous role played by nutrition claims. But how do consumers assess exposure to products' nutritional risk? What factors influence their PNR? To dive deeper into the answers to the questions raised in the introduction, we conducted qualitative research on consumers.

\section{Methodology}

Eighteen men and women of a variety of ages and social backgrounds were interviewed for about $1 \frac{1}{2}$ hours. The number of respondents chosen, 18, was derived from the principle of data saturation (Evrard et al., 2009). Since interviewees often feel more relaxed on sensitive topics when interviewed in their own home (Gavard-Perret et al., 2008), and to allow us to observe them in their home environment, the interviews were immersive, in the individual's kitchen. This also allows the conjunction of observation and verbal reports (Arnould and Wallendorf, 1994). Initially non-directive on the theme of eating anxiety, the interviews then moved onto projective techniques for reasons of simplicity (Evrard et al., 2009). An initial set of photographs illustrating nine food-related situations encountered in the sociological literature (Boutaud, 2004; Fischler and Masson, 2008; Lahlou, 1995) were shown, such as pleasure, anxiety or conviviality. The objective was threefold: to check for the presence of food fears, differentiate health risks from nutritional, and identify any corresponding emotional images. A second set of photographs was then added to the first, showing eight traditional dishes, for example cassoulet (bean and duck or pork stew) or tarte Tatin (upside-down apple pie). 
This enabled us to know whether the PNR differed according to whether the respondent visualized the dish or not, and to explore the representations associated with the two situations. The interview ended with a list of topics about food that had not yet been addressed. A few weeks later, an analysis of shopping-receipts and restaurant bills collected in the meantime made it possible to estimate and compare individual food budgets with those stated.

The interviews were recorded and transcribed, then processed by two successive methods. An analysis across the board using "floating attention" first revealed any common themes (Ayache and Dumez, 2011a, 2011b): in addition to the role of nutrition claims, perceived naturalness, commensality and hyperchoice also appeared. The themes were then used to guide systematic content analysis using the NVivo 8 software package.

\section{Results}

Perception of risk more nutritional than health. To start, all 18 interviewees associate food with health: "I am deeply convinced you can improve your health by food, as well as ruin it too" (Sylvie). Men seemed a little less worried, because it is women who are usually in charge of feeding the family: "Intellectually-speaking, yes, but do I really think about my health when eating?... I must admit, not really, no. (...) I tend to rely on [my wife] for that, she's the one who does the menus" (Jean-Marc). Only two of the respondents manifested no concern about their relation to food at all, even if they do draw an albeit theoretical link between food and health. And yet both were older women and, in theory, more sensitive to the issue of food. The main difference between them and other respondents was that they'd experienced hunger during the war, adding a slant to their attitudes where "people who haven't been in a war (...), since they've never suffered from hunger, are more finicky" (Madeleine).

Although the interviews were conducted during very high-media-profile health and hygiene crises $^{3}$, virtually all the food concerns expressed revolved around nutritional risk. Today's respondents think that food safety is well under control in France. In addition, certain hygiene measures prevent health risks: "All through the cucumber affair, if you're nice and hygienic, wash your hands, and remove the skin and all, you risk nothing" (Marie-Claude). "You've got to cook hamburger steaks properly" (Madeleine). On the other hand, respondents were more at sea with nutritional risk: "There are downsides with sophisticated food, which is much more iffy because you've got those ferments inside them, and you never know how they'll react in several years time" (Claude). "You no longer know what's healthy food because you don't know what to eat any more! Everything's dangerous now. (...) I'm worried about the long-term effects, about cancerous food, that's cancerous in the long-term" (Chantal). Nevertheless, one third of respondents doubted that poor nutrition could go so far as to trigger serious diseases: "There's unquestionably a link between eating and health, (...) but I still don't associate serious disease and food that easily" (Evelyne). "It makes you more or less of a breeding-ground. Then again, to get ill from eating badly, I think you've got to be really over the top" (Adeline). So the long-term nutritional effects on health in the broad sense of the term are cause for concern. Note, however, that the border between health risk and nutritional risk is not always very clear in respondents' minds. For example, almost one half of respondents considered the presence of GMOs or pesticides in food a health risk, despite their being legally-approved, below the Maximum Residue Levels of European law, and of no known short-term risk.

How does PNR work? Based on the present qualitative research, not only is it influenced by product characteristics, but also by consumption situation and purchasing environment. 
Perceived naturalness, a product-related variable. Perceived "naturalness" (literal translation of French naturalité), or the natural character that individuals attribute to foodstuffs, was mentioned extensively by respondents, as shown in Table 2 .

[Table 2]

Foodstuffs thought to be natural are thus thought healthier: "If I start with simple products, I think I'm eating more healthily than if I use manufactured products" (Sylvie). Perceived naturalness seems to decrease PNR: "A home-made cake, yes. (...) It's not an industrial cake, (...) it's better. Even for your health. (...) Everything that's industrial's not good for your health, is it?" (Lucie). This raises the question of claims implying processing of the foodstuff, such as "enriched in X" or "reduced Y". Be this as it may, the consumers interviewed don't all perceive addition and removal in the same way. For them, the term "enriched in X" is worse than "decaffeinated" or "reduced Y" because it raises the question of what it is that it's enriched in: "It's all very well to say 'rich in omega-3', but it depends on where it comes from..." (Claude). It also presupposes a technical operation: "If it says fruit juice enriched in iron, I don't buy it. I prefer normal fruit juice, with nothing added" (Marie).

So how do consumers recognize a "natural" product? As shown in Table 2, respondents highlight ingredients and transformation process. "For it to be healthy, it's got to have as few ingredients as possible" (Thierry). Cooking can also help reduce the perception of nutritional risk, because not only are the ingredients controlled, but the "manufacturing" too. Likewise, if the foodstuff is "calibrated" and "standardized", this too makes it less natural and raises doubts as to mode of production. It is "not necessarily a product made to be good, but a product made to look good. In a sense, it's even a bit suspicious" (Claude). Lastly, respondents express preference for seasonal products and buying from local shops rather than supermarkets associated with industrial production and being "frightening" (Audrey). Rhetoric such as this, however, needs to be taken with some scepticism because an analysis of till receipts reveals that the bulk of their shopping actually is done in supermarkets, for groceries at least, although it's true that meat, fruit and vegetables are often bought from smaller shops. Again, an observation of respondent cupboards revealed the widespread presence of processed food, some of which included a long list of ingredients, somewhat contradicting their declarations: "This one, in theory, has nothing added, if I chose right... Where are the ingredients?... you got to look for the ingredients: cauliflower, carrots, pod peas, courgettes, water, ah!... vegetable fat, butter, vegetable stock... Ah yeah, no, no, rice starch, salt, spices. (...) I can't believe it: I think I must've missed that. (...) Get's on my nerves, that does" (Marie). So the quest for naturalness does not always pass the reality check. Faced with lack of time or money, consumers have to be pragmatic. But skirting their ideals seems to be another source of stress and PNR.

Commensality, a consumption-related variable. Other than the food itself, consumption situation also plays in important role in the respondents' perception, as shown in Table 3.

[Table 3]

For example, respondents associate fatty or sweet food with negative situations, such as disease or anxiety. But put them in front of images of hi-fat or sweet dishes and the language becomes positive again: joie de vivre, convivialité (what English speakers call "sitting down and having a good time together)... "Eating and sharing (...) go together. It's no fun eating on your own. (...) [When you talk about eating in France ], you talk more about sharing. So that's no longer a reason to get stressed. When you share, you might think you're eating too much, but it doesn't stress you. While I think that when you're all alone and eating too much, it does stress you" (Hervé).

In fact, more than what's actually being shared - what's on the plates - is the opportunity of getting together that seems to matter most. Thirteen of the eighteen respondents spontaneously mentioned the social side of food in the open-ended part of the interviews: "It's not so much what you eat as the... the circumstances. For example, when I have friends over at home, I tend to end up cooking something that's not that different from what I usually eat myself, but the atmosphere's very 
different because there's all that nice social thing going on" (Thierry). And even if the food is not that good, respondents still emphasise the beneficial role of sharing: "The canteen's not good, (...) on the other hand, it does get you into the team and, um, sharing mood" (Marie).

Nevertheless, because of its guilt-removing character, commensality could indeed affect the relation between PNR and behaviour. "When you're with friends or family, (...) it's normal to treat yourself. [Guilt] tends to occur more (...) when you get back home one weekday evening, or just feel particularly hungry, and pig yourself on food, then afterwards say, oh dear... I ate too much, that was stupid" (Adeline). Even food that is usually off bounds for the individual becomes temporarily acceptable when sharing: "You go away for the weekend with friends, and there's Nutella for the kids, so you make yourself a nice sarny [sandwich]: for you the Nutella is a once-off and you'd be right to eat it. (...) Alone though, it's no longer a pleasure, no: then you feel guilty" (Marie). So, for respondents, eating is not thought about solely in terms of foodstuff ingested, but also and perhaps above all of consumption situations, which do seem to influence the relation between PNR and behaviour.

Hyperchoice, a purchasing environment-related variable. Eating healthily presupposes nutritional variety. But that complicates both shopping and meals, as illustrated in Table 4.

[Table 4]

Precisely because it's so difficult for them to assess the nutritional characteristics of food while shopping, respondents use comparisons: "It's more relative than absolute" (Thierry). But that takes time and energy: "Shopping for a varied, balanced diet (...) is hard work" (Adeline). The presence of similar-looking products could alert them to a potential nutritional risk: "Out of two tomato sauces: on the one hand you get tomato, carrots, onions and parsley, and on the other it's tomato, onions, parsley, dextrose, modified starch, reconstituted wheat, or reconstituted sugar, and you think jeesh!" (Marie). "Sometimes I go through [the pesto labels] thinking is it?... Is it herbs?... Is it herbs and oil?... Is it herbs, oil and cheese?... or something else altogether?" (Thierry). And an abundant choice exacerbates the sense of uncertainty even more: "What worries you (...) is looking at all the opulence, being sure you've made the right choice. (...) It's not eating, because there'll always be stuff to eat, (...) it's having the choice" (Hervé). And uncertainty is central to the risk perceived. So hyperchoice could increase PNR.

Respondents adopt various strategies to reduce choice, both at home and in the store. "We rarely have very calorie-rich food in the fridge" (Hervé). "I've only got one packet of biscuits that I don't like, in case someone drops in. (...) So, at home, (...), unless I'm having guests, there are no chocolate biscuits, no Nutella. (...) If there is, I'll devour them. (...) I have to put guard-rails up against myself" (Marie). When they go shopping and come up against the abundance of choice, the vast majority of respondents use nutritional risk reducers. Some are intrinsic, such as the perceived naturalness mentioned above, other are extrinsic. For example, numerous respondents mentioned the role of price and brand in looking for healthy food: "To start, I never take the really discount prices" (Evelyne); "For some products, I'm always going to buy brand names" (Laurence); "I start off in the middle of the range, and then I look at the various brands" (Adeline). So, one way for consumers to control PNR seems to be limiting the choice.

Disturbing nutrition claims. As to the nutrition claims themselves, they seem to increase respondent PNR. Where half the interviewees see it as providing information, although not to be taken at absolute face value, the other half is more critical: "It's advertising! (...). You'd have to eat twenty yoghurts a day for years, so all that's just to make it sell, it's marketing" (Chantal). In general, brands are not thought competent to make nutrition claims: "For serious research (...), you need thirty or forty years of hindsight, at least. We're nowhere near that" (Jean-Marc). "Nothing's proven, and the way they're labelled is still (...) a bit ambiguous" (Adeline). And a question mark hangs over the brand 
managers' integrity. "It's not in their interest to nourish us well, those people. (...) They're not there to do us good, (...) they're there to increase their sales" (Laurence). "Most of the time, when they put '0\% fat', it's disloyal advertising because, you know, they replace it by synthetic fat or stuff like that. And it's not necessarily good for your health either" (Jérémy). Adding nutrition claims can even hurt the brand image, judging by verbatims on the oft-cited Danone: "I don't believe the Actimel stuff at all. And yet my daughter-in-law who did agronomy works for Danone. So for us, Danone... everything used to be good, but that I don't believe..." (Marie-Claude). "I trust Danone plain yoghurt. I'd even go so far as to say it's part of my culture. I can't imagine not trusting this brand which has been with me forever. (...) But they don't fool me" (Marie). There may also be a case of cognitive dissonance between the subjective emotional side of the brand and the rational objective principle of the nutrition claims. Brands themselves could be PNR reducers, but the use of claims seems to interfere with this perception. Results such as these pave the way for further research proposals.

\section{Discussion and possible research on PNR}

This qualitative research revealed the importance of PNR in eating-behaviour, an issue already identified in the literature. To start, all respondents associated food with health. This matches domestic surveys conducted by public-health authorities according to whom $80 \%$ of the French think that food has an influence on health (Afsaa and Inpees, 2004). Moreover, the women interviewed seemed even more worried, also in accordance with the literature (Bech-Larsen and Scholderer, 2007; Gomez, 2009b; Grunert and Wills, 2007). Lastly, nutritional risk leads over health-and-hygiene risk: it is not so much spoiled products that consumers are worried about, but the long-term side effects of modern food (Fischler, 2001). For respondents, health risks are better and more easily controlled today, and the feeling of control reduces the perception of risk (Slovic, 1987). On the other hand, doubts revolving around nutritional risk are amplified by ambient "nutritional cacophony" (IREMAS, 2010). The consequences - poorly known, diffuse, and spread out over time generate even more anxiety (Slovic and Peters, 2006). They are also serious for respondents, psychosocially at least, and morbid if not vital in the extreme (Bergadaà and Urien, 2006; WHO and FAO, 2003). It is precisely the uncertainty and extent of the consequences of choice which are the two classic facets of risk perceived (Bauer, 1960; Cox, 1967; Cunningham, 1967; Mitchell, 1999; Taylor, 1974; Volle, 1995), even more so when the issue is human (Rosa, 2003; Slovic, 1987). This explains why long-term nutritional effects are becoming a real issue (Ascher, 2005; Lipovetsky, 2006; Mathé et al., 2008; Pollan, 2009), and justifies both paying attention to and studying PNR and its mechanisms.

\section{Perceived naturalness, a mediating variable in the relation between nutrition claims and PNR?}

Our interviewees were wary of nutrition claims, despite the fact they are designed to provide information on the quality of the products. Not only do the claims not reassure them, but they also raise questions about the food they talk about. In this respect, they seem to increase PNR rather than decrease it. This goes against research in American and British publications (Chandon and Wansink, 2010; Faulkner et al., 2013; Wansink and Chandon, 2006), but supports those in French (Fischler et al., 2010; Gurviez, 2010; Merdji, 2012). The cultural differences mentioned undoubtedly contribute to explaining this, as expressed by the respondents themselves. Rational nutrition claims do not sit well with French social representations of food (Fischler and Masson, 2008; Gurviez, 2010).

But the qualitative research provides a different reading: nutrition claims could raise questions as to perceptions of how natural a product is, intimately associated with the idea of health benefits. The interviews clearly highlighted a heuristic of naturalness. Respondents preferred a simple list of 
known ingredients and minimum product processing, two features defining "preference for natural" (Rozin, 2005a; Rozin et al., 2004). Comparative research has shown this to be more the case in France than the US (Fischler and Masson, 2008). According to the qualitative research, nutrition claims, perceived naturalness and PNR are all related. It thus makes sense to ascertain the following proposal by quantitative means:

P1: Nutrition claims implying food processing (such as "enriched in X" or "reduced in Y") decrease the product's perceived naturalness, thus increasing the consumer's Perception of Nutritional Risk.

Moreover, the interviews conducted confirmed the difference in appreciation of positive and negative claims mentioned in the literature (Burton and Creyer, 2004; Moon and Balasubramanian, 2003; Verbeke et al., 2008). Several explanations have been put forward. Firstly, advertising concentrates on areas where inputs should be limited, such as saturated fats, rather than on what ought to be eaten in sufficient amounts, such as iron (Block and Peracchio, 2006). Next, negative information - for example, reducing saturated fats to reduce cholesterol levels - has more impact than positive - for example, increasing iron intake to improve functioning of the organism - (Moon and Balasubramanian, 2003; Siegrist, 2003; Verbeke et al., 2008). Stated simply, consumers understand it better (Burton and Creyer, 2004). Lastly, there is also an "omission bias" (Rozin et al., 2004) where omitting a nutrient is perceived as more natural than adding one, the latter being associated with human intervention (Rozin, 2005b, 2006).

However, the present research goes further: adding ingredients seems to raise more worries about product nutritional quality than removing them. Verbatims raise the question of congruence with the food. This leads us to consider the influence of type of claim on perceived naturalness and hence on PNR:

P2: Claims such as "enriched in X" decrease the product's perceived naturalness more than those such as "reduced in Y", which implies a higher Perception of Nutritional Risk.

\section{Commensality, a moderating variable of the relation between PNR and behaviour?}

According to the interviews, PNR does not depend solely on product characteristics, but on consumption situation too. This matches Belk's theory highlighting the influence of situation factors on consumer behaviour (Belk, 1974, 1975). In particular, commensality, or sharing your table (mensa) with (cum) other persons (Fischler, 2011; Lardellier, 2011), seems to reduce the stress inherent in eating. Nevertheless, judging by the results of the qualitative research, consumption situations need to be taken into account in greater detail, as illustrated in Fig. 3.

[Figure 3]

The two-by-two highlights the need to differentiate festive from routine meal occasions (Sirieix, 1999). During festive occasions, respondents might knowingly allow themselves to overindulge: commensality thus makes PNR acceptable, which seems to promote taking nutritional risk. On the other hand, routine commensality lets one become alert to PNR due to the gaze of others, and thus limit the taking of nutritional risk. So the presence of third parties seems to play a complex role (de Castro, 2010).

In the literature, research tends to agree on the normative role of the group but also gives results which seem, at least in theory, to be contradictory. Herman and colleagues explain this by the fact that the research refers to three different theoretical frameworks (Herman et al., 2003): (1) According to the social facilitation studies, the presence of others increases food intake (Bell and Pliner, 2003; de Castro, 2010; Pliner et al., 2006; Stroebele and de Castro, 2004), due in particular to 
longer meals reducing people's sense of time and quantities (Wansink, 2006); (2) According to the modelling literature, commensality encourages either increasing or decreasing consumption according to the behaviour of third parties, this being moderated by the latter's corpulence (McFerran et al., 2013); and lastly (3) According to the studies of impression management, commensality reduces food intake when individuals feel themselves to be observed or assessed (Herman et al., 2003), which also explains why women consume fewer less calories in the presence of men (Allen-O'Donnell et al., 2011; Mori et al., 1987).

So based on both the literature and the qualitative research, the link between commensality and eating-behaviour does not seem to be that direct. Commensality could play a moderating role in the relation between PNR and behavioural intention, differing according to festive or non-festive setting. It could promote routine food temperance, but could equally encourage taking nutritional risks in festive situations by removing individuals' inhibitions towards the nutritional risk perceived. Hence the following research proposal, broken down into two sub-proposals:

P3a: In everyday settings, the PNR of an individual who eats meals with others will lead to a more balanced eating-behaviour than if the person eats alone.

P3b: In festive settings, the PNR of an individual who eats meals with others will lead to a less balanced eating-behaviour than if the person eats alone.

\section{Hyperchoice, an explanatory variable of PNR?}

The range of food available today is so huge that it's impossible to know, "food by food, what is edible" (Apfelbaum, 1998). This hyperchoice could accentuate the Perception of Nutritional Risk for food in general, because loss of control generates perception of risk (Slovic, 1987). Judging by the respondents' answers, food combines all the theoretical prerequisites of a hyperchoice situation (Scheibehenne et al., 2010): difficulty in assessing nutritional differences between products (Larceneux, 2003b), judging by comparison because a choice has to be made (Parker and Schrift, 2011), using decision-making heuristics (Gomez, 2009a), and the pressure of time (related to the act of shopping). Admittedly, hyperchoice does increase the objective probability of finding the ideal product among the assortment, but also decreases the subjective experience (Schwartz, 2004). Because it is costly in time and effort, it reduces consumer satisfaction and motivation to choose the product (lyengar and Lepper, 2000; Larceneux et al., 2007). The "paradox of choice" could explain the lack of PNR in the two respondents who went hungry during the war by "hedonistic adaptation" (Schwartz, 2004), a psychological process allowing individuals to get used to situations of pleasure or displeasure and hence tolerate deprivation. But in situations of abundance, hedonistic adaptation causes dissatisfaction, because the pleasure felt ends up proving less than the pleasure anticipated (Schwartz, 2004). Which might also explain why the French, less exposed to hyperchoice, seem less stressed by food than the Americans too (Rozin et al., 2006).

According to our qualitative research, however, the purchasing environment and in particular the size of the assortment also influence the PNR specific to a given food, which is a new result. Judging by the verbatims, one and the same product can trigger different PNRs according to whether it is placed among a large or small assortment, because product abundance leads respondents to think about the product differences. In particular, this may encourage them to compare ingredients and then think about nutritional quality, which they doubtlessly would not have considered in a reduced-choice setting. Hence our final proposal:

P4: A given product's PNR is higher in conditions of food hyperchoice, than in a reducedchoice setting. 


\section{Conclusion}

Based upon a review of multidisciplinary literature and eighteen in-depth interviews of consumers, the present article contributes to a better understanding of the mechanisms of Perception of Nutritional Risk. From a theoretical point of view, it proposes a new conceptual framework for PNR. According to the protection motivation theory (Maddux and Rogers, 1983; Rogers, 1975), PNR - via its two components of probability of occurrence and severity of threat (Bauer, 1960) - must occur prior to a change in eating-behaviour. The present qualitative research allows us to consider new variables influencing either PNR itself or the link between PNR and behavioural intention, as illustrated in Fig. 4.

\section{[Figure 4]}

Perceived naturalness seems to play a mediating role in the relation between nutrition claims and PNR. Nutrition claims implying food processing (such as "enriched in X" or "reduced in Y") would decrease a product's perceived naturalness, in turn increasing the food's PNR. Commensality would seem to moderate the relation between PNR and behavioural intention in different ways according to whether the setting is festive (leading to taking increased nutritional risk) or routine (encouraging a more balanced eating-behaviour). Lastly, hyperchoice seems to increase the PNR of a given food compared to a reduced-choice setting.

The authors acknowledge that using photographs of traditional dishes and consumption situations as respondent stimuli may have exaggerated the importance of naturalness and commensality. Despite this, naturalness was mentioned spontaneously during the open-ended part of the interviews prior to the projective exercises by all eighteen respondents, and commensality by thirteen. Experiments ascertaining the existence of suspected relations between the variables, based here on qualitative interviews, would be particularly worthwhile. In addition, as emphasised in various parts of the paper, a cultural component is essential in PNR, indicating that the present results may not apply outside the setting of France. Studying these relations in other countries would also be worthwhile.

From a managerial and social point of view, the present research also illustrates the complexity of eating-behaviour mechanisms. This puts a question mark over the predominating education model KABP - Knowledge, Attitudes, Beliefs and Practices -, promoted by the World Health Organisation (Calandre et al., 2009; WHO, 1990). The model postulates the existence of a linear relation between knowledge, attitude, beliefs and habits in terms of health. If that were so, all we'd need to improve behaviour would be to inform the public. But food and eating are more complex than that (Calandre et al., 2009), as the present research also shows. PNR appears to be an antecedent of behavioural intention, and itself seems influenced by numerous factors related to the food itself (nutrition claims and perceived naturalness), consumption situation (commensality), purchasing environment (hyperchoice) or individual (attitude towards nutritional risk). Further, some of the relations seem to be direct, others mediating, others yet again moderating, and hence the interactions. So it's not just a question of spoon-feeding consumers with information for them to be consciously aware of nutritional risk and adapt their behaviour accordingly.

So what implications do these results have for public-health authorities? According to the present research, perceived naturalness decreases PNR. And the agrifood industry is perfectly aware of this. A recent trade press article 4 recommended firms to use "one of the many other ways of conveying naturalness without using the word 'natural' (...) to not get bogged down in a regulatory minefield", and give their products a "health halo [which will] increase sales significantly". So to avoid deceit, it seems necessary to fight signals suggesting non-proven naturalness, especially if the products have a questionable nutritional profile. In terms of hyperchoice, the public-health authorities could make it easier for consumers to make "virtuous" choices by means of clear, legible and well-understood labelling. They could also communicate what a review of the literature tells us: that "low-cal" products does not mean "eat as much as you like". This, as for cigarettes, is not 
something the French necessarily know. Lastly, concerning commensality, public-health authorities should encourage people to eat their daily meals together as a family, and not concentrate their advertising solely on nutrients as is still often the case around the world (Bublitz et al., 2013; Fischler and Masson, 2008). In France, the latest versions of the PNNS (Programme National Nutrition Santé, or national nutrition \& health programme) and PNA (Programme National pour l'Alimentation, or national eating programme) now mention a "symbolic and social sides of eating" (PNNS) and a "mealtime conviviality" (PNA). This is also a trend in recent research recommendations, the paradigm of food well-being, defined as a "a positive psychological, physical, emotional, and social relationship with food at both the individual and societal levels" (Block et al., 2011; Bublitz et al., 2013). Given the present research, this holistic approach to food, giving room to hedonistic and social aspects, seems quite appropriate.

\section{Acknowledgements}

The authors would like to express their thanks to the Editor-in-Chief, Joël Brée, as well as three anonymous readers for their constructive comments which have seriously improved the article. 
Tables

\begin{tabular}{|c|c|}
\hline \multicolumn{2}{|c|}{ Food risk } \\
\hline Health risk & Nutritional risk \\
\hline $\begin{array}{l}\text { - Extrinsic to the food: poisoning by } \\
\text { contamination (Ferreira, 2006) }\end{array}$ & $\begin{array}{l}\text { - Intrinsic to the food: side effects of nutritional } \\
\text { imbalance (Ferreira, 2006) }\end{array}$ \\
\hline Short-term effect (Aurier and Sirieix, 2009) & - Long-term effect (Aurier and Sirieix, 2009) \\
\hline - On physical health (Aurier and Sirieix, 2009) & $\begin{array}{l}\text { - On physical, mental and social health (Aurier } \\
\text { and Sirieix, 2009; WHO, 1946) }\end{array}$ \\
\hline - Neophobia protects you (Fischler, 1990) & - Neophilia protects you (Fischler, 1990) \\
\hline $\begin{array}{l}\text { - Collective responsibility (Fischler, 1990; } \\
\text { Lipovetsky, 2006) }\end{array}$ & $\begin{array}{l}\text { - Individual responsibility (Fischler, 1990; } \\
\text { Lipovetsky, 2006) }\end{array}$ \\
\hline
\end{tabular}

Table 1. Health and nutritional aspects of food risk

\begin{tabular}{|lcc|}
\hline \multicolumn{1}{|c|}{ Terms used (or same family) } & Occurrences & $\begin{array}{c}\text { Number of respondents } \\
\text { involved }\end{array}$ \\
\hline Cooking & 125 & 18 \\
Ingredients & 69 & 16 \\
Nature/Natural & 46 & 12 \\
Simple & 28 & 12 \\
Industry & 24 & 10 \\
Processed & 19 & 7 \\
Standardised / Calibrated & 14 & 4 \\
Traditional & 14 & 6 \\
Chemistry (Chemical) & 11 & 7 \\
\hline
\end{tabular}

Table 2. Lexical analysis, occurrences on the theme of naturalness.

\begin{tabular}{|lcc|}
\hline Terms used (or same family) & Occurrences & $\begin{array}{c}\text { Number of respondents } \\
\text { involved }\end{array}$ \\
\hline Pleasure & 118 & 18 \\
Meal(s) & 113 & 17 \\
Friends & 74 & 13 \\
Table & 41 & 15 \\
Alone & 34 & 11 \\
Sharing & 28 & 7 \\
Family & 25 & 10 \\
Together & 21 & 10 \\
Convivial & 18 & 8 \\
Grandparents & 16 & 9 \\
Generation & 4 & 4 \\
\hline
\end{tabular}

Table 3. Lexical analysis, occurrences on the theme of commensality. 


\begin{tabular}{|lcc|}
\hline \multicolumn{1}{|c}{ Terms used (or same family) } & Occurrences & Number of respondents involved \\
& & \\
\hline Looking / Checking & 258 & 18 \\
Choice / Choosing & 82 & 16 \\
Variety & 31 & 11 \\
Looking for & 31 & 15 \\
Too much of & 22 & 11 \\
Criterion & 20 & 9 \\
Assess & 14 & 12 \\
Ration / limit / reduce & 12 & 7 \\
Compare & 8 & 5 \\
Relative & 8 & 5 \\
Decision & 8 & 6 \\
\hline
\end{tabular}

Table 4. Lexical analysis, occurrences on the theme of hyperchoice. 


\section{Figures}

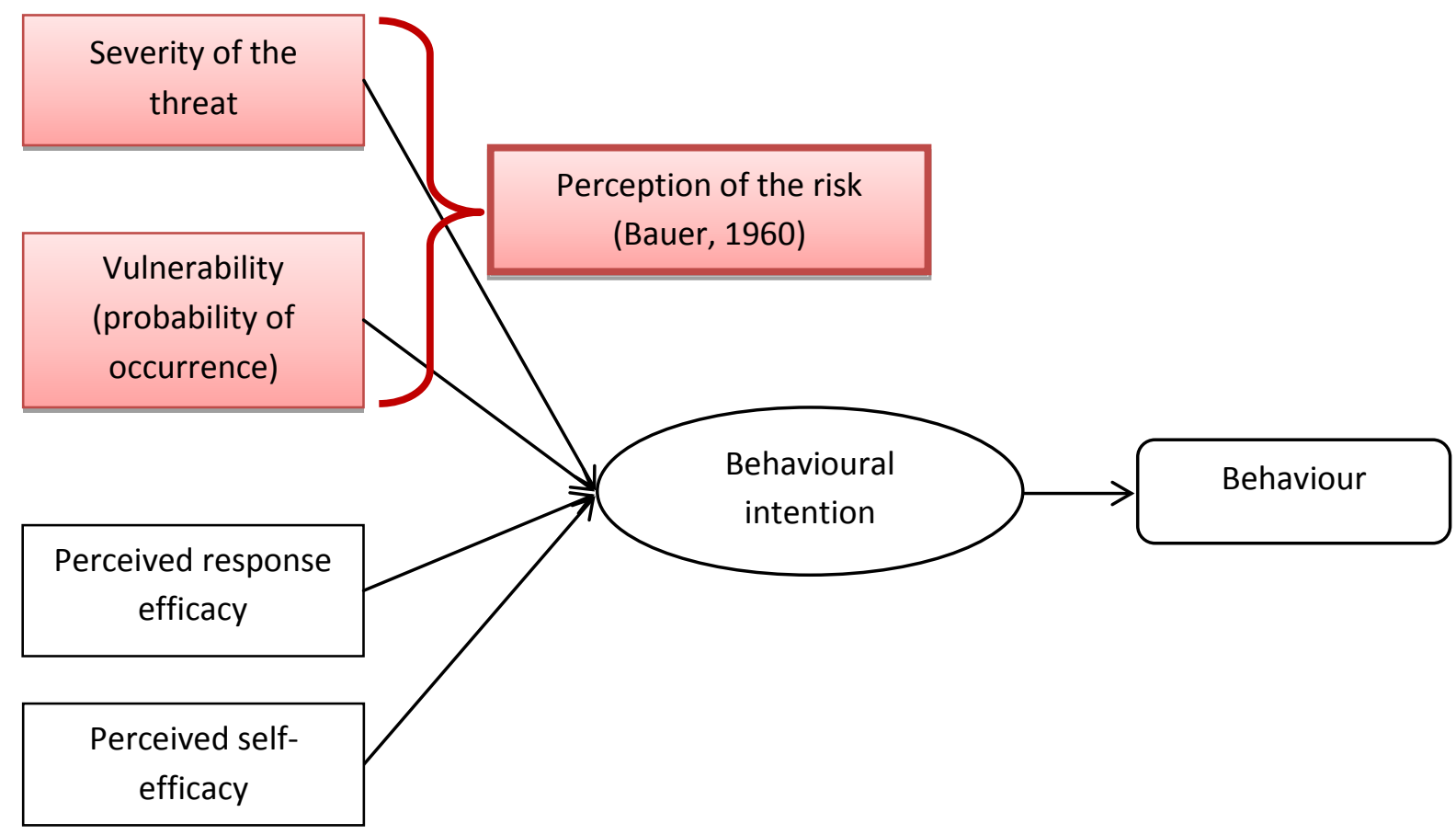

Figure 1. Position of perception of risk in Rogers' protection motivation theory (Maddux and Rogers, 1983; Rogers, 1975).

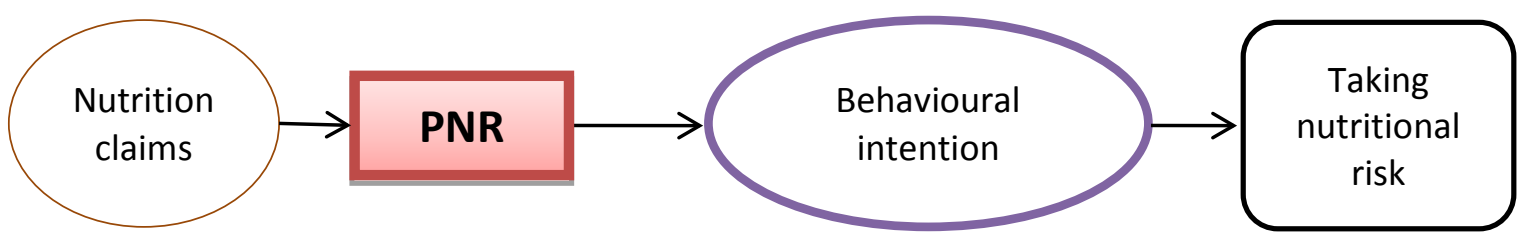

Figure 2. Literature review of PNR mechanisms and influences. 


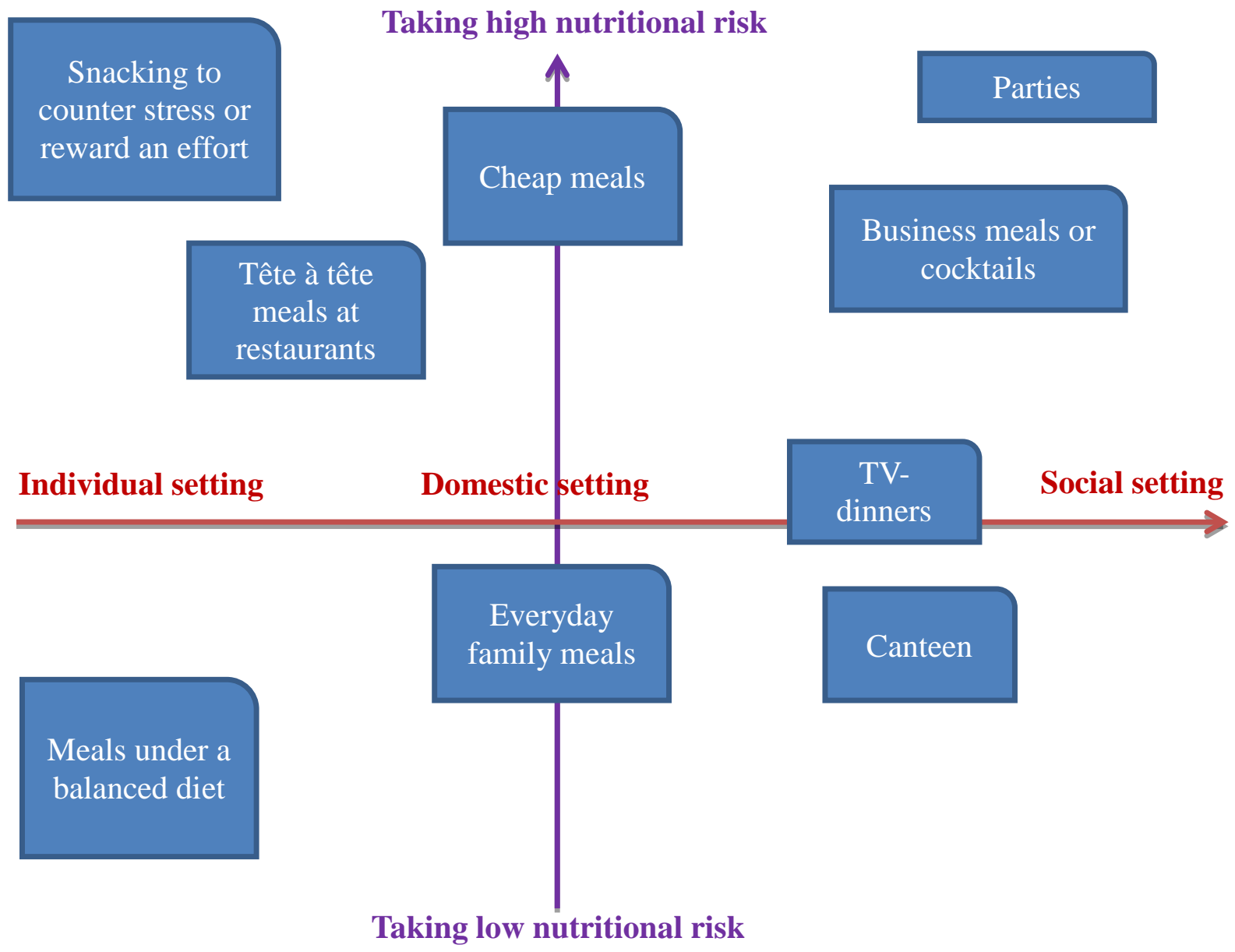

Figure 3. Taking of nutritional risk differing according to consumption situation.

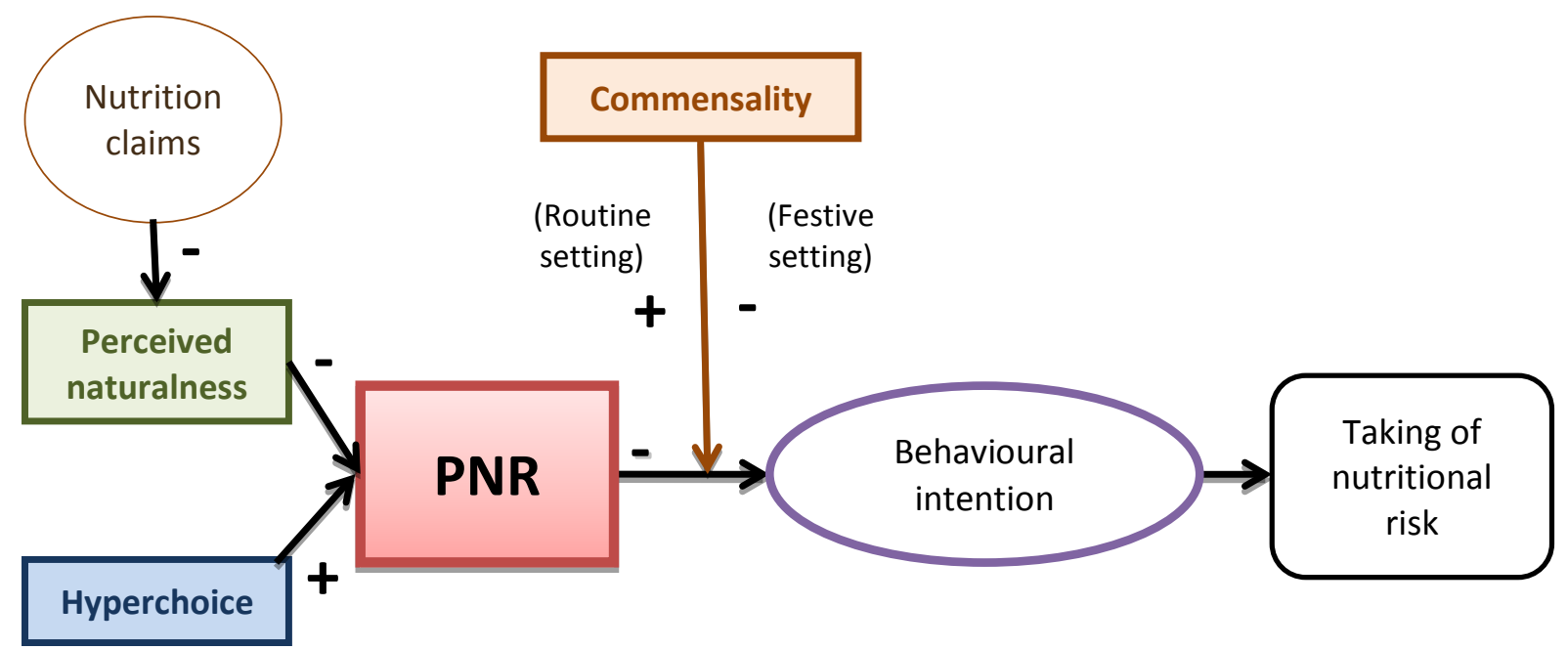

Figure 4. Proposal for a conceptual framework of PNR. 


\section{Bibliography}

Afsaa and Inpees (2004) Comparaison de deux enquêtes nationales de consommation alimentaire auprès des adolescents et des adultes (Baromètre Santé Nutrition 2002 et INCA 1998-99) : éléments de méthode et résultats.

Ajzen I (1991) The theory of planned behavior. Organizational Behavior \& Human Decision Processes 50(2): 179-211.

Ajzen I and Fishbein M (1980) Understanding attitudes and predicting social behavior. Englewood Cliffs, NJ: Prentice-Hall.

Allen-O'Donnell M, Cottingham MD, Nowak TC, et al. (2011) Impact of group settings and gender on meals purchased by college students. Journal of Applied Social Psychology 41(9): 2268-2283.

Andrews JC, Netemeyer RG and Burton S (1998) Consumer generalization of nutrient content claims in advertising. Journal of Marketing 62(4): 62-75.

Apfelbaum M (1998) Risques et peurs alimentaires. Paris: Odile Jacob.

Arnould EJ and Wallendorf M (1994) Market-oriented ethnography: interpretation building and marketing strategy formulation. Journal of Marketing Research 31(4): 484-504.

Ascher F (2005) Le mangeur hypermoderne : une figure de l'individu éclectique. Paris: Odile Jacob.

Aurier P and Sirieix L (2009) Marketing des produits agroalimentaires. Paris: Dunod.

Ayache $\mathrm{M}$ and Dumez H (2011a) Le codage dans la recherche qualitative : une nouvelle perspective ? Le Libellio d'Aegis, CRG Polytechnique 7(2): 33-46.

Ayache M and Dumez H (2011b) Réflexions en forme de réponses: à propos du codage dans la recherche qualitative. Le Libellio d'Aegis, CRG Polytechnique 7(3): 29-34.

Bauer R (1960) Consumer behavior as risk taking. In: Dynamic marketing for a changing world, proceedings of the 43rd conference of the AMA, Chicago: American Marketing Association, pp. 389398.

Bech-Larsen T and Scholderer J (2007) Functional foods in Europe: consumer research, market experiences and regulatory aspects. Trends in Food Science \& Technology 18(4): 231-234.

Belk RW (1974) An exploratory assessment of situational effects in buyer behavior. Journal of Marketing Research (JMR) 11(2): 156-163.

Belk RW (1975) Situational variables and consumer behavior. Journal of Consumer Research 2(3): 157-164.

Bell R and Pliner PL (2003) Time to eat : the relationship between the number of people eating and meal duration in three lunch settings. Appetite 41(2): 215-218.

Bergadaà M and Urien B (2006) Le risque alimentaire perçu comme risque vital de consommation : émergences, adaptation et gestion. Revue Française de Gestion 32(162): 127-144. 
Block LG and Peracchio LA (2006) The calcium quandary: how consumers use nutrition labels. Journal of Public Policy \& Marketing 25(2): 188-196.

Block LG, Grier SA, Childers TL, et al. (2011) From nutrients to nurturance : a conceptual introduction to food well-being. Journal of Public Policy \& Marketing 30(1): 5-13.

Boutaud J-J (2004) L'imaginaire de la table: convivialité, commensalité et communication. Paris: L'Harmattan.

Brée J (2010) Marketing, alimentation et obésité infantile. Revue Management et Avenir (37): 93-96.

Brownell $\mathrm{K}$ and Warner $\mathrm{K}$ (2009) The perils of ignoring history : big tobacco played dirty and millions died. How similar is big food? The Milbank Quarterly 87(1): 259-294.

Brunel O and Pichon P-E (2004) Food-related risk-reduction strategies : purchasing and consumption processes. Journal of Consumer Behaviour 3(4): 360-374.

Bublitz MG, Peracchio LA, Andreasen AR, et al. (2013) Promoting positive change : advancing the food well-being paradigm. Journal of Business Research 66(8): 1211-1218.

Burton S and Creyer EH (2004) What consumers don't know can hurt them : consumer evaluations and disease risk perceptions of restaurant menu items. Journal of Consumer Affairs 38(1): 121-145.

Calandre N, Bricas N and Sirieix L (2009) Comment les mères perçoivent-elles les risques nutritionnels de leurs enfants? Une approche par le paradigme psychométrique au Vietnam. Economies et sociétés (31): 1735-1760.

Camous R (2011) Ados et prises de risques... Quelles actions de communication pour les sensibiliser aux dangers du tabac, de l'alcool, de la route, etc.?. Paris: Editions EMS Management \& Société.

Chandon P (2012) How package design and packaged-based marketing claims lead to overeating. INSEAD Working Papers Collection (61): 1-40.

Chandon P and Ordabayeva N (2009) Supersize in one dimension, downsize in three dimensions: effects of spatial dimensionality on size perceptions and preferences. Journal of Marketing Research 46(6): 739-753.

Chandon P and Wansink B (2007a) Is obesity caused by calorie underestimation ? A psychophysical model of meal size estimation. Journal of Marketing Research 44(1): 84-99.

Chandon P and Wansink B (2007b) The biasing health halos of fast-food restaurant health claims : lower calorie estimates and higher side-dish consumption intentions. Journal of Consumer Research 34(3): 301-314.

Chandon P and Wansink B (2010) Is food marketing making us fat? A multi-disciplinary review. Foundations \& Trends in Marketing 5(3): 1-86.

Chernev A and Gal D (2010) Categorization effects in value judgments : averaging bias in evaluating combinations of vices and virtues. Journal of Marketing Research 47(4): 738-747.

Chevallier L (2009) Tout savoir sur les aliments : vérités et impostures. Paris: LGF Livre de Poche. 
Cox DF (1967) Risk taking and information handling in consumer behaviour. Boston: Harvard University Press.

Cunningham SM (1967) The major dimensions of perceived risk. In: Risk taking and information handling in consumer behaviour, Boston: Harvard University Press, pp. 82-108.

De Castro JM (2010) The control of food intake of free-living humans: putting the pieces back together. Physiology \& Behavior 100(5): 446-453.

Douglas $M$ and Wildavsky $A B$ (1983) Risk and culture: an essay on the selection of technical and environmental dangers. Berkeley, CA: University of California Press.

Evrard Y, Pras B, Roux E, et al. (2009) Market : fondements et méthodes des recherches en marketing. Paris: Dunod.

Faulkner GP, Pourshahidi LK, Wallace JMW, et al. (2013) Perceived 'healthiness' of foods can influence consumers' estimations of energy density and appropriate portion size. International journal of obesity (2005).

Ferreira C (2006) Food information environments: risk communication and advertising imagery. Journal of Risk Research 9(8): 851-868.

Ferrières M (2006) Histoire des peurs alimentaires : du Moyen Age à l'aube du XXe siècle. Paris: Seuil.

Fischler C (1990) L'homnivore. Paris: Odile Jacob.

Fischler C (2001) La peur est dans l'assiette. Revue Française du Marketing 183/184(3/4): 7-10.

Fischler C (2011) Commensality, society and culture. Social Science Information 50(3-4): 528-548.

Fischler C and Masson E (2008) Manger: Français, Européens et Américains face à l'alimentation. Paris: Odile Jacob.

Fischler C, Merdji M, Michels S, et al. (2010) Etude EuroAllégations. Etude européenne réalisée en souscription pour des industriels de l'agroalimentaire, Paris: Protéines et BrainValue.

Fishbein M and Ajzen I (1975) Belief, attitude, intention and behavior : an introduction to theory and research. Boston: Addison-Wesley Publishing.

Flandrin JL and Montanari M (1996) Histoire de l'alimentation. Paris: Fayard.

Frazer J-G (1911) Le rameau d'or. Paris: Robert Laffont (1998).

Gallen C (2001) Le besoin de réassurance en consommation alimentaire. Revue Française du Marketing 183/184(3/4): 67-85.

Garg N, Wansink B and Inman JJ (2007) The influence of incidental affect on consumers' food intake. Journal of Marketing 71(1): 194-206. 
Garretson JA and Burton S (2000) Effects of nutrition facts panel values, nutrition claims, and health claims on consumer attitudes, perceptions of disease-related risks, and trust. Journal of Public Policy \& Marketing 19(2): 213-227.

Gavard-Perret M-L, Gotteland D, Haon C, et al. (2008) Méthodologie de la Recherche, réussir son mémoire ou sa thèse en sciences gestion. Paris: Pearson.

Gomez P (2008) La nutrition dans les stratégies d'innovation alimentaire : de la protection du risque de santé publique à la construction de l'avantage concurrentiel. Décisions Marketing (49): 71-83.

Gomez P (2009a) Les heuristiques de choix nutritionnels : une étude qualitative exploratoire. In: Journées de Recherche en Marketing de Bourgogne, Dijon, pp. 1-25.

Gomez $\mathrm{P}$ (2009b) L'orientation régulatrice de santé : déterminants, mesure et conséquences sur les comportements de santé et le traitement de l'information. PhD thesis, IAE Université de Nantes, France.

Grunert KG and Wills JM (2007) A review of European research on consumer response to nutrition information on food labels. Journal of Public Health 15(5): 385-399.

Gurviez P (2001) Le rôle de la confiance dans la perception des risques alimentaires par les consommateurs. Revue Française du Marketing 183/184(3/4): 87-98.

Gurviez P (2010) 'Et là je dis attention arnaque!' Evitement et résistance des consommateurs envers une marque qui leur veut du bien. In: Journées de Recherche en Marketing de Bourgogne, Dijon, pp. 56-78.

Herman CP, Roth DA and Polivy J (2003) Effects of the presence of others on food intake: a normative interpretation. Psychological Bulletin 129(6): 873-886.

IREMAS (2010) Livre blanc cacophonie alimentaire et nutritionnelle. Jouy-en-Josas: Institut pour la Recherche en Marketing de l'Alimentation Santé.

lyengar SS and Lepper MR (2000) When choice is demotivating : can one desire too much of a good thing? Journal of Personality \& Social Psychology 79(6): 995-1006.

Kahneman D and Tversky A (1979) Prospect theory : an analysis of decision under risk. Econometrica 47(2): 263-291.

Kapferer J-N (1998) Les marques, base de la confiance? In: Risques et peurs alimentaires, Paris: Odile Jacob, pp. 203-210.

Kaplan LB, Szybillo GJ and Jacoby J (1974) Components of perceived risk in product purchase : a cross-validation. Journal of Applied Psychology 59(3): 287-291.

Keller SB, Landry M, Olson J, et al. (1997) The effects of nutrition package claims, nutrition facts panels, and motivation to process nutrition information on consumer product evaluations. Journal of Public Policy \& Marketing 16(2): 256-269.

Kermisch C (2011) Le concept du risque : de l'épistémologie à l'éthique. Paris: Tec \& Doc. 
Kozup JC, Creyer EH and Burton S (2003) Making healthful food choices: the influence of health claims and nutrition information on consumers' evaluations of packaged food products and restaurant menu items. Journal of Marketing 67(2): 19-34.

Kytle B and Ruggie JG (2005) Corporate social responsibility as risk management: z model for multinationals, Papier de recherche Corporate social responsibility as risk management. Boston: John F. Kennedy School of Government, Harvard University.

Lahlou S (1995) Penser-manger : les représentations sociales de l'alimentation. PhD thesis, Ecole des Hautes Etudes en Sciences Sociales, Paris, France.

Larceneux F (2003a) Segmentation des signes de qualité : labels expérientiels et labels techniques. Décisions Marketing (29): 35-46.

Larceneux F (2003b) Stratégies de signalisation de la qualité : l'impact des labels sur le processus de décision des consommateurs. PhD thesis, Université Paris-Dauphine, France.

Larceneux F, Rieunier S and Fady A (2007) The Effect of Hyperchoice on the Consumer and the Moderating Effect of the Brand: An Application in the Jewelry Market. Recherche et Applications en Marketing 22(4): 43-57.

Lardellier P (2011) Opéra bouffe : une anthropologie gourmande de nos modes alimentaires. Paris: Editions EMS Management \& Société.

Latham MC (2001) Human nutrition in the developing world. In: Food and Nutrition Series, Rome: FAO.

Lipovetsky G (2006) Le bonheur paradoxal : essai sur la société d'hyperconsommation. Paris: Gallimard.

Lone TA, Pence D, Levi AE, et al. (2009) Marketing healthy food to the least interested consumers. Journal of Foodservice 20(2): 90-99.

Maddux JE and Rogers RW (1983) Protection motivation and self-efficacy : a revised theory of fear appeals and attitude change. Journal of Experimental Social Psychology 19(5): 469-479.

Mason CF (2009) Certification of socially responsible behavior: eco-labels and fair-trade coffee. Journal of Agricultural \& Food Industrial Organization (7): 1-19.

Mathé T, Pilorin T and Hébel P (2008) Du discours nutritionnel aux représentations de l'alimentation, Cahier de recherche $n^{\circ} 252$. Paris: Crédoc.

McCann MT, Wallace JMW, Robson PJ, et al. (2013) Influence of nutrition labelling on food portion size consumption. Appetite (65): 153-158.

McFerran B, Dahl DW, Fitzsimons GJ, et al. (2013) I'll have what she's having: effects of social influence and body type on the food choices of others. Journal of Consumer Research 36(6): 915-929.

Merdji M (2006) L'imaginaire du dégoût : une approche anthropologique de l'univers émotionnel de I'alimentation. In: Recherches en Management et Organisation, Paris: Economica, pp. 179-194. 
Merdji M (2010) Consumers' perception and uses of nutritional and health claims. In: AgroParisTech.

Merdji M (2012) Profils nutritionnels. In: Dictionnaire des cultures alimentaires, Presses Universitaires de France, pp. 1101-1106.

Méric J, Pesqueux Y and Solé A (2009) La société du risque : analyse et critique. Paris: Economica.

Michel G (2004) Au coeur de la marque : les clés du management de la marque. Paris: Dunod.

Mishra A, Mishra H and Masters TM (2012) The influence of bite size on quantity of food consumed: a field study. Journal of Consumer Research 38(5): 791-795.

Mitchell V-W (1999) Consumer perceived risk : conceptualisations and models. European Journal of Marketing 33(1/2): 6-195.

Moon W and Balasubramanian S (2003) Willingness to pay for non-biotech foods in the U.S. and U.K. Journal of Consumer Affairs 37(2): 317-339.

Moore ES and Rideout VJ (2007) The online marketing of food to children : is it just fun and games? Journal of Public Policy \& Marketing 26(2): 202-220.

Mori D, Chaiken S and Pliner P (1987) 'Eating lightly' and the self-presentation of femininity. Journal of Personality and Social Psychology 53(4): 693-702.

Nestle M (2007) Food politics : how the food industry influences nutrition and health. Berkeley, CA: University of California Press.

Parker JR and Schrift RY (2011) Rejectable choice sets : how seemingly irrelevant no-choice options affect consumer decision processes. Journal of Marketing Research 48(5): 840-854.

Pennings JME, Wansink B and Meulenberg MTG (2002) A note on modeling consumer reactions to a crisis : the case of the mad cow disease. International Journal of Research in Marketing 19(1): 91100.

Pidgeon N, Kasperson RE and Slovic P (2003) The social amplification of risk. Cambridge, UK: Cambridge University Press.

Pliner P, Bell R, Hirsch ES, et al. (2006) Meal duration mediates the effect of 'social facilitation' on eating in humans. Appetite 46(2): 189-198.

Pollan M (2009) In defense of food : an eater's manifesto. New York: Penguin Books.

Poulain J-P (2002) Sociologies de l'alimentation : les mangeurs et l'espace social alimentaire. Paris: Presses Universitaires de France.

Rogers RW (1975) A protection motivation theory of fear appeals and attitude change. The Journal of Psychology 91(1): 93-114.

Rosa EA (2003) The logical structure of the social amplification of risk framework (SARF): metatheoretical foundations and policy implications. In: The social amplification of risk, Cambridge, UK: Cambridge University Press, pp. 47-79. 
Roselius R (1971) Consumer rankings of risk reduction methods. Journal of Marketing 35(1): 56-61.

Rozin P (2005a) The meaning of food in our lives: a cross-cultural perspective on eating and wellbeing. Journal of Nutrition Education \& Behavior (37): 107-112.

Rozin P (2005b) The meaning of 'natural'. Psychological Science 16(8): 652-658.

Rozin P (2006) Naturalness judgments by lay Americans : process dominates content in judgments of food or water acceptability and naturalness. Judgment and Decision Making 1(2): 91-97.

Rozin P, Millman L and Nemeroff C (1986) Operation of the laws of sympathetic magic in disgust and other domains. Journal of Personality and Social Psychology 50(4): 703-712.

Rozin P, Spranca M, Krieger Z, et al. (2004) Preference for natural : instrumental and ideational/moral motivations, and the contrast between foods and medicines. Appetite 43(2): 147-154.

Rozin P, Fischler C, Shields C, et al. (2006) Attitudes towards large numbers of choices in the food domain : a cross-cultural study of five countries in Europe and the USA. Appetite 46(3): 304-308.

Saulais L, Doyon M, Ruffieux B, et al. (2012) Consumer knowledge about dietary fats : another French paradox? British Food Journal 114(1): 108-120.

Scheibehenne B, Greifeneder R and Todd PM (2010) Can there ever be too many options? A metaanalytic review of choice overload. Journal of Consumer Research 37(3): 409-425.

Schuldt JP, Muller D and Schwarz N (2012) The 'fair trade' effect health halos from social ethics claims. Social Psychological and Personality Science 3(5): 581-589.

Schwartz B (2004) The paradox of choice : why more is less. New York: Harper Perennial.

Sharpe KM, Staelin R and Huber J (2008) Using extremeness aversion to fight obesity: policy implications of context dependent demand. Journal of Consumer Research 35(3): 406-422.

Siegrist M (2003) Perception of gene technology, and food risks : results of a survey in Switzerland. Journal of Risk Research 6(1): 45-60.

Simon HW, Berkowitz NN and Moyer RJ (1970) Similarity, credibility, and attitude change : a review and a theory. Psychological Bulletin;Psychological Bulletin 73(1): 1-16.

Singh J and Sirdeshmukh D (2000) Agency and trust mechanisms in consumer satisfaction and loyalty judgments. Journal of the Academy of Marketing Science 28(1): 150-167.

Sirieix L (1999) La consommation alimentaire : problématiques, approches et voies de recherche. Recherche et Applications en Marketing 14(3): 41-58.

Sirieix L and Dubois P-L (1999) Vers un modèle qualité-satisfaction intégrant la confiance. Recherche et Applications en Marketing 14(3): 1-22.

Slovic P (1987) Perception of risk. Science 236(4799): 280 -285. 
Slovic P and Peters E (2006) Risk perception and affect. Current Directions in Psychological Science 15(6): 322-325.

Stroebele N and de Castro JM (2004) Effect of ambience on food intake and food choice. Nutrition 20(9): 821-838.

Taylor JW (1974) The role of risk in consumer behavior. Journal of Marketing 38(2): 54-60.

Tversky A and Kahneman D (1992) Advances in prospect theory: cumulative representation of uncertainty. Journal of Risk \& Uncertainty 5(4): 297-323.

Verbeke W, Vanhonacker F, Frewer LJ, et al. (2008) Communicating risks and benefits from fish consumption : impact on Belgian consumers' perception and intention to eat fish. Risk Analysis: An International Journal 28(4): 951-967.

Volle P (1995) Le concept de risque perçu en psychologie du consommateur : antécédents et statut théorique. Recherche et Applications en Marketing 10(1): 39-56.

Wansink B (2006) Mindless eating : why we eat more than we think. New York: Bantam Dell.

Wansink B and Chandon P (2006) Can 'low-fat' nutrition labels lead to obesity? Journal of Marketing Research (43): 605-617.

Werle C, Boesen-Mariani S, Gavard-Perret M-L, et al. (2012) Preventing Youth Obesity: The Efficacy of the Social Risk Argument on Eating Intentions and Behaviors. Recherche et Applications en Marketing 27(3): 3-29.

WHO (1946) Preamble to the constitution of the World Health Organization. In: Official proceedings of the World Health Organization, p. 100.

WHO (1990) WHO global programme on AIDS : social and behavioural research. Disasters 14(3): 276281.

WHO and FAO (2003) Diet, nutrition and the prevention of chronic diseases Report of a joint WHO/FAO expert consultation. In: Technical Report Series, Geneva: WHO.

Wilcox K, Vallen B, Block L, et al. (2009) Vicarious goal fulfillment: when the mere presence of a healthy option leads to an ironically indulgent decision. Journal of Consumer Research 36(3): 380393.

Zingg A, Cousin M-E, Connor M, et al. (2013) Public risk perception in the total meat supply chain. Journal of Risk Research 16(8): 1005-1020. 
APPENDIX A1: Overview of papers published in journals or major books on the link between nutrition claims and PNR

\begin{tabular}{|c|c|c|c|}
\hline References & Main objective & Questions raised and methodology & Main results for the present study \\
\hline $\begin{array}{l}\text { (Andrews et al., } \\
\text { 1998) }\end{array}$ & $\begin{array}{l}\text { To highlight the health } \\
\text { halo effect of nutrition } \\
\text { claims }\end{array}$ & $\begin{array}{l}\text { Do consumers understand nutritional claims ? Do } \\
\text { they generalize the nutritional benefits to other } \\
\text { foods? } \\
\text { Inter-subject experiments, } 365 \text { consumers }\end{array}$ & $\begin{array}{l}\text { This study is the first to demonstrate the health halo effect: presented } \\
\text { with nutrition claims, consumers also infer superior nutritional qualities } \\
\text { for other nutrients not mentioned. }\end{array}$ \\
\hline $\begin{array}{l}\text { (Burton and } \\
\text { Creyer, 2004) }\end{array}$ & $\begin{array}{l}\text { To assess the influence } \\
\text { of nutrition information } \\
\text { provided in restaurant } \\
\text { menus }\end{array}$ & $\begin{array}{l}\text { How do nutrition information, health claims, and } \\
\text { presentation influence consumers' judgment? } \\
\text { Inter-subject experiment, } 377 \text { respondents. }\end{array}$ & $\begin{array}{l}\text { Consumers attach more credibility to nutritional information than to } \\
\text { health claims, but health claims influence perception and credibility } \\
\text { according to context. } \\
\text { Consumers interpret negative information more easily than positive } \\
\text { information. }\end{array}$ \\
\hline $\begin{array}{l}\text { (Chandon and } \\
\text { Ordabayeva, } \\
\text { 2009) }\end{array}$ & $\begin{array}{l}\text { To measure the effects of } \\
\text { changes in spatial } \\
\text { dimensions on perceived } \\
\text { quantities }\end{array}$ & $\begin{array}{l}\text { How do individuals assess changes in portion size } \\
\text { or packaging? How does it influence their } \\
\text { consumption and their purchasing decisions? } \\
5 \text { experiments, hundreds of people }\end{array}$ & $\begin{array}{l}\text { The more dimensions there are, the more consumers underestimate the } \\
\text { amount contained and magnitude of the changes, which leads to } \\
\text { overconsumption. This research highlights size and format bias. }\end{array}$ \\
\hline $\begin{array}{l}\text { (Chandon and } \\
\text { Wansink, } \\
\text { 2007a) }\end{array}$ & $\begin{array}{l}\text { To construct a } \\
\text { psychophysical model } \\
\text { for estimating the } \\
\text { number of calories in a } \\
\text { meal }\end{array}$ & $\begin{array}{l}\text { Do overweight people underestimate the energy } \\
\text { content of their meal more than people of normal } \\
\text { weight, and why? How can assessment bias be } \\
\text { reduced? What is the situation with regard to } \\
\text { dieticians? } \\
4 \text { studies: } 55 \text { then } 156 \text { students under laboratory } \\
\text { conditions, } 147 \text { adults in the field, } 405 \text { dieticians } \\
\text { under laboratory conditions }\end{array}$ & $\begin{array}{l}\text { The greater the number of calories, the more it is underestimated; the } \\
\text { smaller the number, the more it is overestimated, regardless of BMI and } \\
\text { nutrition implications. Overweight people underestimate the calories } \\
\text { from their meal more than people of normal weight, but only because } \\
\text { they eat larger quantities: bias occurs more. Telling people about this } \\
\text { bias is not enough to solve the problem. On the other hand, breaking } \\
\text { down calories by dish allows the total number of calories to be better } \\
\text { estimated for large quantities. } \\
\text { The same bias is observed among dieticians, but is less pronounced. }\end{array}$ \\
\hline $\begin{array}{l}\text { (Chandon and } \\
\text { Wansink, } \\
\text { 2007b) }\end{array}$ & $\begin{array}{l}\text { What is the effect on } \\
\text { consumption of the } \\
\text { health positioning of } \\
\text { certain fast foods? }\end{array}$ & $\begin{array}{l}\text { Is there a health halo effect in fast food restaurants? } \\
\text { How can it be reduced? } \\
4 \text { experiments: one in the field ( } 518 \text { respondents at } \\
\text { McDonald's or Subway), } 3 \text { under laboratory } \\
\text { conditions ( } 316,46 \text { and } 214 \text { students) }\end{array}$ & $\begin{array}{l}\text { Health claims lead consumers to underestimate the calories in main } \\
\text { dishes in fast food restaurants and to choose more calorific side orders } \\
\text { and drinks. Consumers are not aware of these biases. Developing critical } \\
\text { thinking by consumers regarding nutrition reduces health halo effect. }\end{array}$ \\
\hline
\end{tabular}




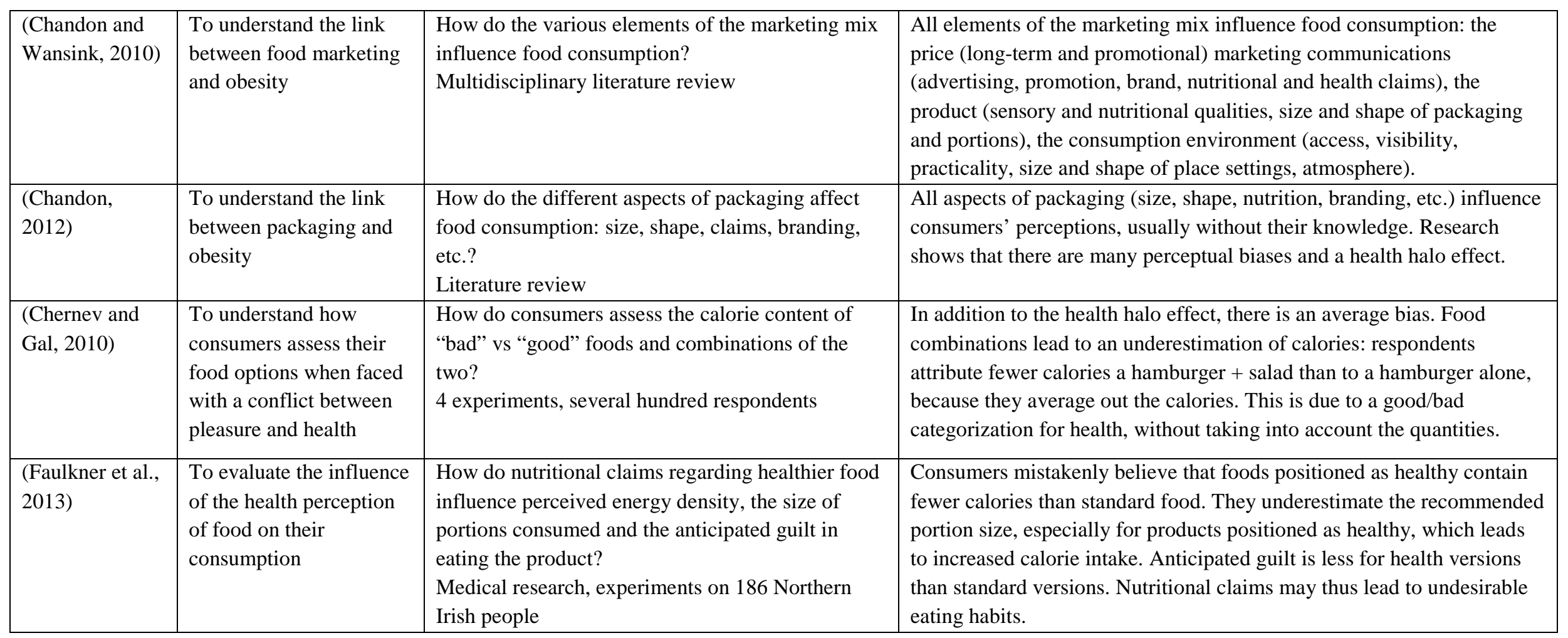




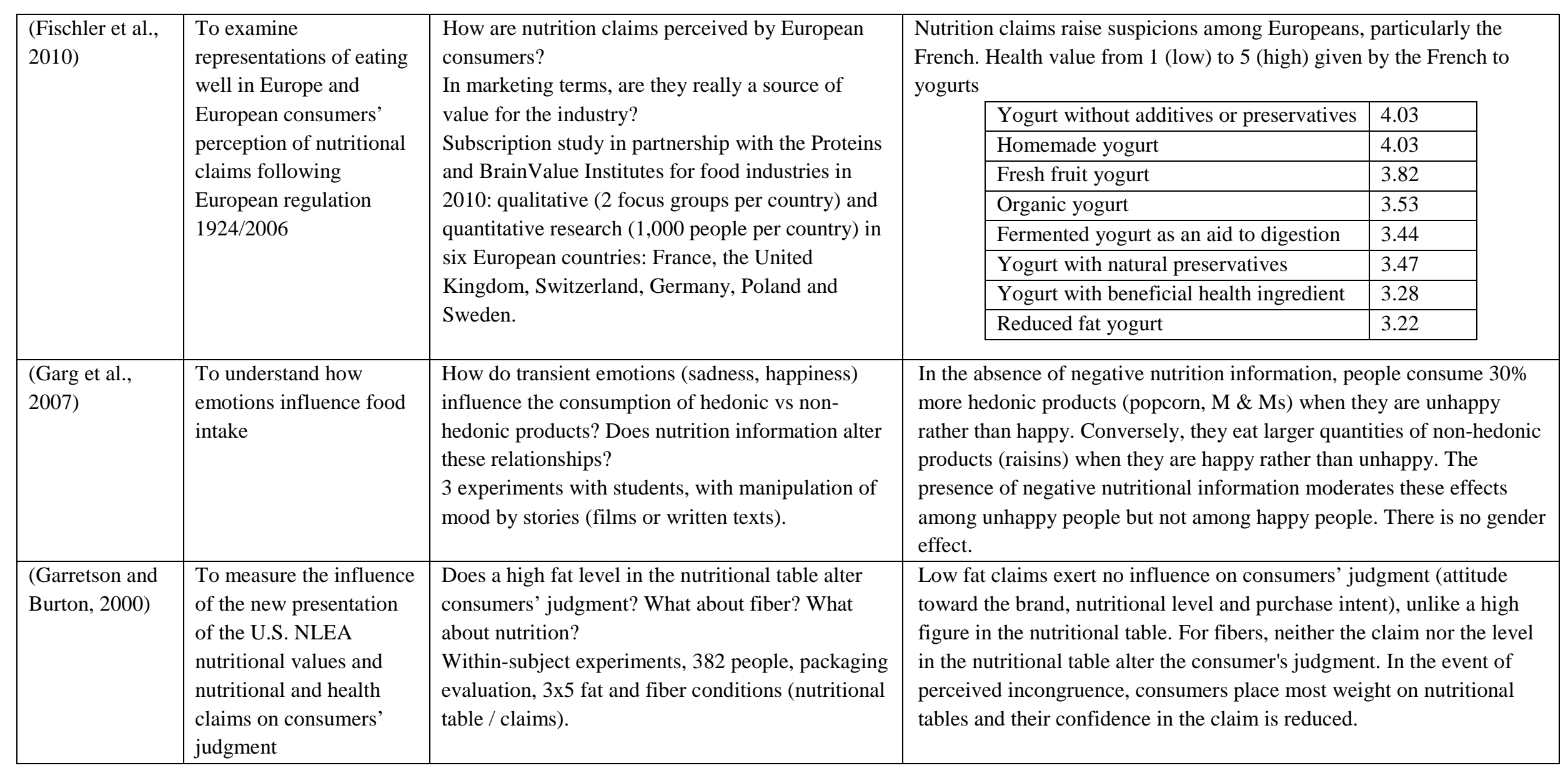




\begin{tabular}{|c|c|c|c|}
\hline $\begin{array}{l}\text { (Keller et al., } \\
\text { 1997) }\end{array}$ & $\begin{array}{l}\text { To assess the effect of } \\
\text { the new US nutritional } \\
\text { tables (NLEA) on } \\
\text { consumers' perception }\end{array}$ & $\begin{array}{l}\text { What are the effects of health claims, nutritional } \\
\text { tables and motivation on consumers' evaluations } \\
\text { since the introduction of the NLEA in 1994? } \\
\text { Inter-subject experiment, } 460 \text { people. }\end{array}$ & $\begin{array}{l}\text { Consumers have more confidence in nutritional values than in claims: } \\
\text { nutritional values are of more use for making choices, while claims are } \\
\text { viewed as marketing and generate suspicion. The presence of claims } \\
\text { does not improve the consumer's perception or purchase intentions if } \\
\text { they not consistent with nutritional values. Such claims then undermine } \\
\text { the credibility of the manufacturer. }\end{array}$ \\
\hline $\begin{array}{l}\text { (Kozup et al., } \\
\text { 2003) }\end{array}$ & $\begin{array}{l}\text { To evaluate the influence } \\
\text { of nutrition information } \\
\text { and health claims placed } \\
\text { on restaurant menus and } \\
\text { product packaging }\end{array}$ & $\begin{array}{l}\text { What is the influence of health claim vs. nutrition } \\
\text { information on the consumer's assessment and } \\
\text { perceived health risk? } \\
3 \text { within-subject experiments, lasagna sold in } \\
\text { supermarkets or on a restaurant menu. }\end{array}$ & $\begin{array}{l}\text { Nutrition information influences the consumer's assessment (attitude, } \\
\text { purchase intention) more than the health claim does. Consumers pay } \\
\text { more attention to nutrition information than to claims. In the context of } \\
\text { restaurants, consumers react more strongly to negative information. If } \\
\text { information about other products are more negative than those of the } \\
\text { target product, attitudes and purchase intentions toward the target } \\
\text { product increase. }\end{array}$ \\
\hline $\begin{array}{l}\text { (Lone et al., } \\
\text { 2009) }\end{array}$ & $\begin{array}{l}\text { To market healthy eating } \\
\text { among the least } \\
\text { interested consumers }\end{array}$ & $\begin{array}{l}\text { How can a healthier diet be promoted among } \\
\text { consumers who are not interested in nutrition? } \\
\text { Questionnaires to } 520 \text { Californian students. }\end{array}$ & $\begin{array}{l}\text { It is better not to highlight nutrition messages for men, because unlike } \\
\text { for women, it puts them off products. }\end{array}$ \\
\hline $\begin{array}{l}\text { (McCann et al., } \\
\text { 2013) }\end{array}$ & $\begin{array}{l}\text { To evaluate the influence } \\
\text { of nutrition claims on the } \\
\text { size of portion } \\
\text { consumed }\end{array}$ & $\begin{array}{l}\text { How do reduced fat nutrition claims influence the } \\
\text { amount consumed? } \\
\text { Medical research, experiments with } 47 \text { people in } \\
\text { Northern Ireland, } 3 \text { identical meals but standard } \\
\text { information vs high fat and calorie content vs low } \\
\text { fat and calorie content }\end{array}$ & $\begin{array}{l}\text { The quantity consumed and energy intake were significantly increased } \\
\text { when fat and calorie content were low, but identical between standard } \\
\text { and high fat and calorie content. Men and overweight individuals most } \\
\text { increase the quantity consumed when there is low fat and calorie } \\
\text { content. This finding suggests that reduced fat nutrition claims are a } \\
\text { factor in overconsumption. }\end{array}$ \\
\hline
\end{tabular}




\begin{tabular}{|c|c|c|c|c|c|}
\hline \multirow[t]{6}{*}{$\begin{array}{l}\text { (Merdji, 2010, } \\
\text { 2012) }\end{array}$} & \multirow{6}{*}{$\begin{array}{l}\text { Study of the effects of } \\
\text { the European Regulation } \\
\text { 1924/2006: influence of } \\
\text { nutrition claims on } \\
\text { French consumers' } \\
\text { perception of health and } \\
\text { naturalness }\end{array}$} & \multirow{6}{*}{$\begin{array}{l}\text { What health value and naturalness value do } \\
\text { consumer attribute to foods according to the claims } \\
\text { they carry? } \\
\text { ANR survey conducted by M Merdji, G Debucquet } \\
\text { and C Fischler on } 1000 \text { French adults in December } \\
\text { 2009: combination of interviews, questionnaires } \\
\text { and experimental economics methods (auctions) } \\
\text { for several product categories }\end{array}$} & \multicolumn{3}{|c|}{$\begin{array}{l}\text { There is a gap between the health value expressed by claims and the } \\
\text { health value perceived by French consumers. } \\
\text { E.g. ham, scores } 1 \text { (low) to } 10 \text { (high) }\end{array}$} \\
\hline & & & Type of ham & Health value & Naturalness value \\
\hline & & & Organic & 6.47 & 7.11 \\
\hline & & & Standard & 5.40 & 5.54 \\
\hline & & & Low fat & 5.19 & 4.45 \\
\hline & & & Added omega 3 & 4.15 & 3.43 \\
\hline $\begin{array}{l}\text { (Mishra et al., } \\
\text { 2012) }\end{array}$ & $\begin{array}{l}\text { To study the influence of } \\
\text { bite size on the amount } \\
\text { consumed }\end{array}$ & $\begin{array}{l}\text { Why and how does bite size does affect the amount } \\
\text { eaten? } \\
\text { Experiments in a restaurant then in the laboratory. } \\
\text { Manipulation of bite size by the size of fork } \\
\text { provided }\end{array}$ & \multicolumn{3}{|c|}{$\begin{array}{l}\text { Smaller bite sizes increase the amount consumed in restaurants. The } \\
\text { theory of motivation provides the explanation: for the restaurant, the } \\
\text { aim is to be full and thus be profitable. The laboratory study shows that } \\
\text { when these factors are absent, the result is reversed. }\end{array}$} \\
\hline $\begin{array}{l}\text { (Saulais et al., } \\
\text { 2012) }\end{array}$ & $\begin{array}{l}\text { To compare the } \\
\text { relationship between } \\
\text { nutrition knowledge and } \\
\text { food choices in } 3 \\
\text { countries }\end{array}$ & $\begin{array}{l}\text { What nutrition knowledge about fat do consumers } \\
\text { have in the US vs France vs Quebec? } \\
\text { Questionnaires, about } 100 \text { people per } \\
\text { country/province }\end{array}$ & \multicolumn{3}{|c|}{$\begin{array}{l}\text { A new French paradox? US consumers have much more nutrition } \\
\text { knowledge about fat than the French, yet the obesity rate is three times } \\
\text { higher in the US than in France. }\end{array}$} \\
\hline $\begin{array}{l}\text { (Schuldt et al., } \\
\text { 2012) }\end{array}$ & $\begin{array}{l}\text { To measure the effect of } \\
\text { fair trade claims on PNR }\end{array}$ & $\begin{array}{l}\text { Do fair-trade-related claims produce a health halo } \\
\text { effect? } \\
2 \text { experiments ( } 56 \text { adults, } 192 \text { students) }\end{array}$ & \multicolumn{3}{|c|}{$\begin{array}{l}\text { Fair trade labeled chocolate is perceived as containing fewer calories. } \\
\text { This inference is made even without the presence of any claims, if the } \\
\text { company is described as treating its employees well. }\end{array}$} \\
\hline
\end{tabular}




\begin{tabular}{|c|c|c|c|}
\hline $\begin{array}{l}\text { (Sharpe et al., } \\
\text { 2008) }\end{array}$ & $\begin{array}{l}\text { To show the value of } \\
\text { using aversion to } \\
\text { extremes to combat } \\
\text { obesity }\end{array}$ & $\begin{array}{l}\text { How does the range of soda formats offered by } \\
\text { fast-food outlets influence the consumer's choice } \\
\text { and energy intake? } \\
3 \text { within-subject experiments, scenarios and real } \\
\text { environment, hundreds of adults }\end{array}$ & $\begin{array}{l}\text { Consumers are averse to extremes: adding a larger format to the range } \\
\text { offered or removing the smallest increases individual consumption. It is } \\
\text { important to take into account the reference system in public policy: to } \\
\text { reduce calorie intake, adding a smaller format is effective because it } \\
\text { leads consumers to choose smaller portions. }\end{array}$ \\
\hline $\begin{array}{l}\text { (Verbeke et al., } \\
\text { 2008) }\end{array}$ & $\begin{array}{l}\text { To assess the influence } \\
\text { of communication } \\
\text { regarding nutritional } \\
\text { risks and/or benefits on } \\
\text { consumption of fish and } \\
\text { perception of its } \\
\text { attributes in Belgium }\end{array}$ & $\begin{array}{l}\text { How do consumers process positive (omega } 3 \text { and } \\
\text { vitamin D) and negative (dioxins and mercury) } \\
\text { aspects in nutrition communication? } \\
\text { What is the influence of the source of information } \\
\text { and perceived credibility? } \\
\text { Experiment on } 381 \text { women }\end{array}$ & $\begin{array}{l}\text { The "benefits" condition increases consumption intention by } 21 \% \text { but } \\
\text { does not basically change the already very positive perception of } \\
\text { attributes (ceiling effect). The "risks" condition sharply reduces the } \\
\text { perception of attributes, but less than consumption intentions (by 8\%) } \\
\text { since the message is not viewed as credible or trustworthy. The } \\
\text { "benefits then risks" and "risks then benefits" conditions reduce the } \\
\text { perception of attributes but do not significantly change consumption } \\
\text { intention. }\end{array}$ \\
\hline $\begin{array}{l}\text { (Wansink and } \\
\text { Chandon, 2006) }\end{array}$ & $\begin{array}{l}\text { To assess the effect of } \\
\text { the "low fat content" } \\
\text { claim on consumption }\end{array}$ & $\begin{array}{l}\text { Do "low-fat content" claims increase consumption? } \\
\text { What role do the feeling of guilt and estimated } \\
\text { portion size play? Does the specification of portion } \\
\text { size eliminate these potential biases? } \\
3 \text { experiments, hundreds of adults }\end{array}$ & $\begin{array}{l}\text { Participants unknowingly eat up to } 50 \% \text { more when food is presented as } \\
\text { low-fat. In people of normal weight, this is especially true for "healthy" } \\
\text { products (Granola). Among overweight people, it concerns hedonic and } \\
\text { healthy products, and in even higher proportions. In fact, the claim } \\
\text { diminishes the feeling of guilt and leads to underestimation of the } \\
\text { calorie content, hence an overestimation of the appropriate portion size. }\end{array}$ \\
\hline $\begin{array}{l}\text { (Wilcox et al., } \\
\text { 2009) }\end{array}$ & $\begin{array}{l}\text { To study the effect of } \\
\text { personal monitoring of } \\
\text { eating behavior }\end{array}$ & $\begin{array}{l}\text { How does the presence of healthier foods influence } \\
\text { people's selection depending on their level of } \\
\text { personal monitoring? } \\
4 \text { experiments, several hundred students }\end{array}$ & $\begin{array}{l}\text { Ironically, the mere presence of a healthier food in an assortment of } \\
\text { unhealthy leads individuals with high personal monitoring to choose the } \\
\text { less healthy foods. }\end{array}$ \\
\hline
\end{tabular}


APPENDIX A2: Profile of interviewees

\begin{tabular}{|c|c|c|c|c|c|c|c|}
\hline $\begin{array}{l}\text { First } \\
\text { name }\end{array}$ & Gender & Age & Location & $\begin{array}{l}\text { Type of } \\
\text { residence }\end{array}$ & $\begin{array}{c}\text { Family } \\
\text { situation }\end{array}$ & Education & Job \\
\hline Adeline & F & 38 & $\begin{array}{l}\text { Paris } \\
\text { suburbs }\end{array}$ & Apartment & $\begin{array}{l}\text { Married } \\
\text { Children }\end{array}$ & $\begin{array}{l}\text { Baccalaureate } \\
+5 \text { yrs }\end{array}$ & Manager \\
\hline Anne & F & 15 & $\begin{array}{l}\text { Paris } \\
\text { suburbs }\end{array}$ & $\begin{array}{l}\text { Detached } \\
\text { house }\end{array}$ & $\begin{array}{l}\text { Living with } \\
\text { parents }\end{array}$ & Diploma & $\begin{array}{l}\text { Junior high } \\
\text { school } \\
\text { student }\end{array}$ \\
\hline Audrey & $\mathrm{F}$ & 26 & $\begin{array}{l}\text { Paris } \\
\text { suburbs }\end{array}$ & $\begin{array}{l}\text { Detached } \\
\text { house }\end{array}$ & $\begin{array}{l}\text { Married } \\
\text { Infant }\end{array}$ & $\begin{array}{l}\text { Technical } \\
\text { school cert. }\end{array}$ & Hairdresser \\
\hline Chantal & F & 67 & Paris & Apartment & Separated & Baccalaureate & $\begin{array}{l}\text { No } \\
\text { occupation }\end{array}$ \\
\hline Claude & $\mathrm{M}$ & 62 & $\begin{array}{l}\text { Rhône- } \\
\text { Alpes }\end{array}$ & Village house & Married & $\begin{array}{l}\text { Baccalaureate } \\
+2\end{array}$ & $\begin{array}{l}\text { Retired } \\
\text { schoolteacher }\end{array}$ \\
\hline Evelyne & $\mathrm{F}$ & 60 & $\begin{array}{l}\text { Rhône- } \\
\text { Alpes }\end{array}$ & Village house & Married & $\begin{array}{l}\text { Baccalaureate } \\
+2\end{array}$ & $\begin{array}{l}\text { Retired } \\
\text { schoolteacher }\end{array}$ \\
\hline Hervé & $\mathrm{M}$ & 43 & $\begin{array}{l}\text { Paris } \\
\text { suburbs }\end{array}$ & $\begin{array}{l}\text { Deatched } \\
\text { house }\end{array}$ & $\begin{array}{l}\text { Married } \\
\text { Children }\end{array}$ & $\begin{array}{l}\text { Baccalaureate } \\
+2\end{array}$ & Manager \\
\hline Jan & $M$ & 30 & Paris & Tenant & Single & $\begin{array}{l}\text { Baccalaureate } \\
+5\end{array}$ & Unemployed \\
\hline Jean-Marc & $\mathrm{M}$ & 58 & $\begin{array}{l}\text { Rhône- } \\
\text { Alpes }\end{array}$ & $\begin{array}{l}\text { Out-of-town } \\
\text { apartment }\end{array}$ & Married & $\begin{array}{l}\text { Baccalaureate } \\
+5\end{array}$ & Teacher \\
\hline Jérémy & $\mathrm{M}$ & 19 & $\begin{array}{l}\text { Paris } \\
\text { suburbs }\end{array}$ & Townhouse & $\begin{array}{l}\text { Living with } \\
\text { parents }\end{array}$ & $\begin{array}{l}\text { Technical } \\
\text { school cert. }\end{array}$ & $\begin{array}{l}\text { High school } \\
\text { student }\end{array}$ \\
\hline Laurence & F & 45 & $\begin{array}{l}\text { Paris } \\
\text { suburbs }\end{array}$ & $\begin{array}{l}\text { Detached } \\
\text { house }\end{array}$ & $\begin{array}{l}\text { Married } \\
\text { Children }\end{array}$ & $\begin{array}{l}\text { Baccalaureate } \\
+2\end{array}$ & Cadre \\
\hline Lucie & F & 19 & $\begin{array}{l}\text { Paris } \\
\text { suburbs }\end{array}$ & Townhouse & $\begin{array}{l}\text { Living with } \\
\text { parents }\end{array}$ & $\begin{array}{l}\text { Technical } \\
\text { school cert. }\end{array}$ & $\begin{array}{l}\text { High school } \\
\text { student }\end{array}$ \\
\hline Madeleine & $\mathrm{F}$ & 85 & $\begin{array}{l}\text { Rhône- } \\
\text { Alpes }\end{array}$ & $\begin{array}{l}\text { Detached } \\
\text { house }\end{array}$ & Widow & Diploma & Retired \\
\hline Maria & F & 49 & $\begin{array}{l}\text { Paris } \\
\text { suburbs }\end{array}$ & Townhouse & $\begin{array}{l}\text { Married } \\
\text { Children }\end{array}$ & $\begin{array}{l}\text { Vocational } \\
\text { training cert. }\end{array}$ & $\begin{array}{l}\text { Cleaning } \\
\text { woman }\end{array}$ \\
\hline Marie & $\mathrm{F}$ & 41 & Paris & Studio & Single & $\begin{array}{l}\text { Baccalaureate } \\
+5\end{array}$ & $\begin{array}{l}\text { Unemployed } \\
\text { manager }\end{array}$ \\
\hline $\begin{array}{l}\text { Marie- } \\
\text { Claude }\end{array}$ & F & 68 & Limousin & Village house & $\begin{array}{l}\text { Married } \\
\text { Grandmother }\end{array}$ & Diploma & $\begin{array}{l}\text { No } \\
\text { occupation }\end{array}$ \\
\hline Sylvie & F & 55 & $\begin{array}{l}\text { Rhône- } \\
\text { Alpes }\end{array}$ & $\begin{array}{l}\text { Out-of-town } \\
\text { apartment }\end{array}$ & Married & $\begin{array}{l}\text { Baccalaureate } \\
+2\end{array}$ & $\begin{array}{l}\text { No } \\
\text { occupation }\end{array}$ \\
\hline Thierry & $\mathrm{M}$ & 28 & Normandy & $\begin{array}{l}\text { House in } \\
\text { small town }\end{array}$ & Single & $\begin{array}{l}\text { Baccalaureate } \\
+5\end{array}$ & Manager \\
\hline
\end{tabular}


APPENDIX A3: Interview guide

At start of the interview, in a non-directive manner:

"What scares you in relation to your diet? Why?"

Ask the consumer to present his/her kitchen (equipment, food, etc.)

\section{Projective exercises:}

- Submit a list of high-risk foods (see chart) and note response in accordance with projective methods: linking these risks to photos of people provided by us (seemingly healthy, overweight, sick, etc.). See first set of photos

- Show photographs of classic dishes and note response [both objective and subjective]. See second set of photos

Continuation of the interview in a semi-directive manner:

- If they have not been mentioned, introduce the following themes:

o How much importance do you attach to your diet and what role does it play for you? [health, well-being, appearance]

o What does enjoying yourself when you eat mean to you? When you want to enjoy food, what do you eat? [pleasure, the forbidden, transgression, naturalness]

o Do you worry about your diet? Why?

o Do you worry about your family's diet? Why?

0 Is it hard to eat healthily? What solutions do you have?

o How do you decide whether a product is good for your health?

o Who/what does you trust for obtaining nutrition information? And who/what do you not trust? What puts you on the alert? Do you look at information on the packaging? What do you think about nutrition claims?

o Give examples of brands, labels and companies that make you trust the nutritional quality of their products, and say why. And examples of those that do not?

- At the end of the interview, make a note of the following information on the consumer:

0 First name, age, place of residence

o Family situation, number and age of children

o Educational level, profession, household income

o The household's approximate weekly or monthly expenditure on food

o The state of health of the interviewee and his/her family.

- Ask the interviewee to keep his/her food check-out receipts for the next two weeks. Leave an envelope to put these in, and make another appointment in two weeks time. 


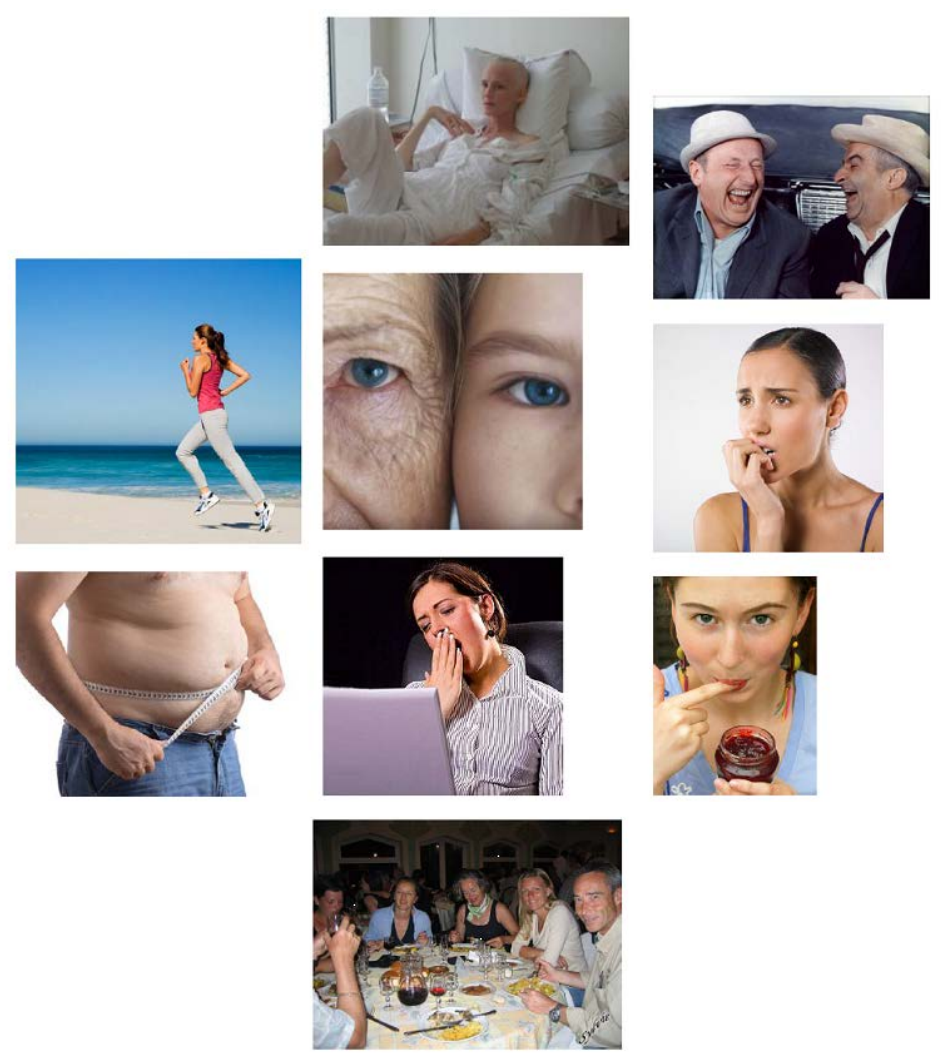

First set of photographs: exercise on food risks

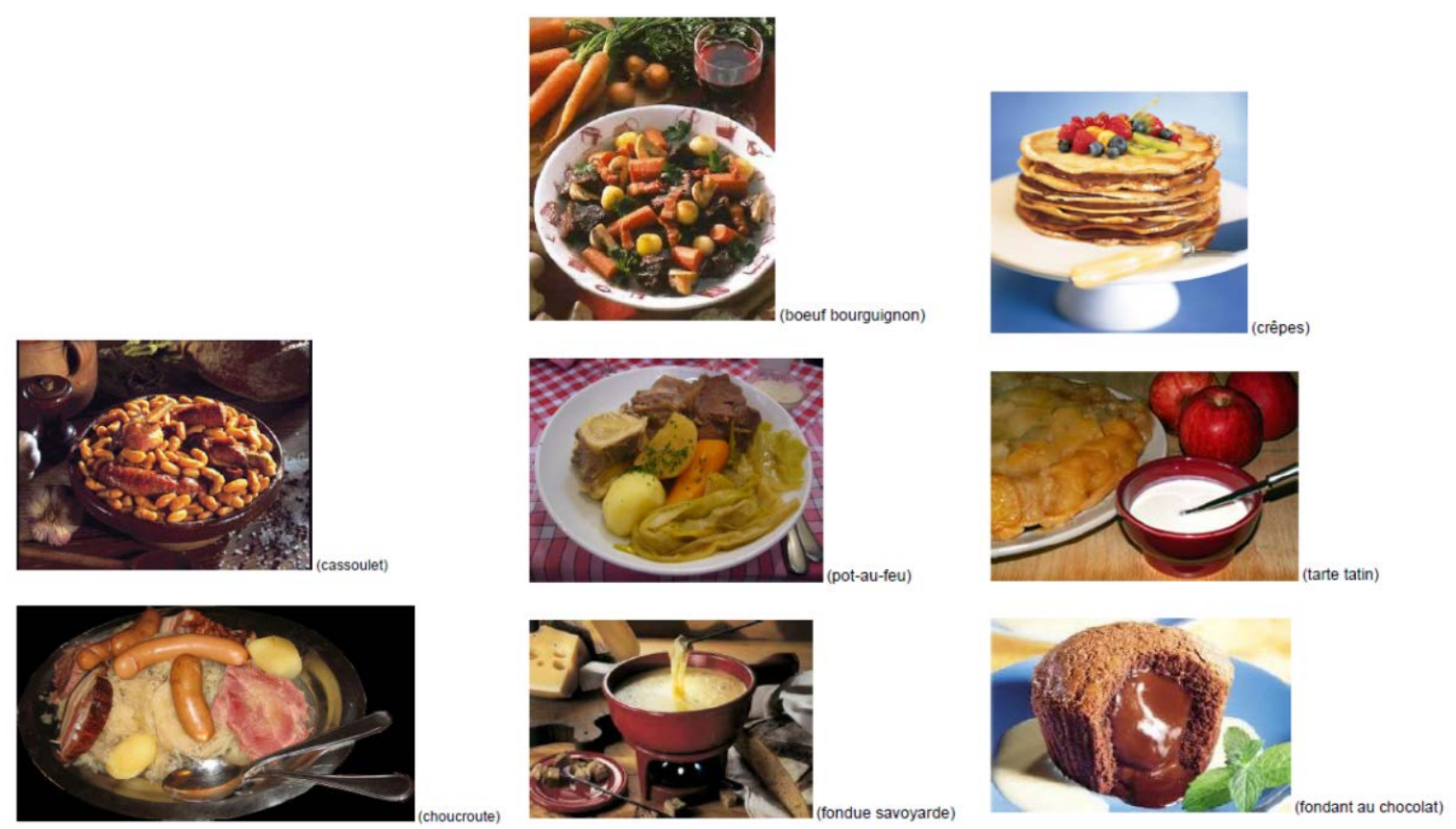

Second set of photographs: exercise on classic dishes 


\begin{tabular}{|c|c|c|c|c|c|c|c|c|c|c|c|c|}
\hline $\begin{array}{l}\text { Risks then dishes (each } \\
\text { presented in random order) }\end{array}$ & 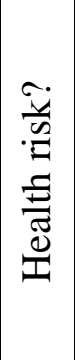 & 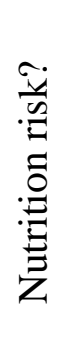 & 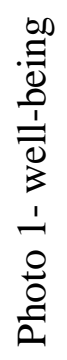 & 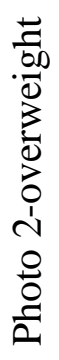 & 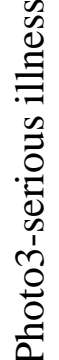 & 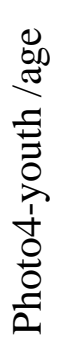 & 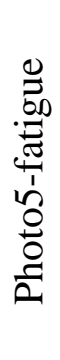 & 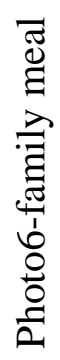 & 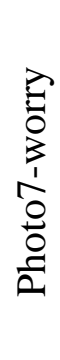 & 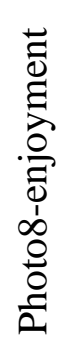 & 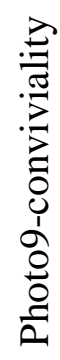 & 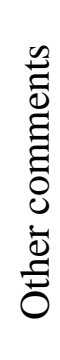 \\
\hline
\end{tabular}

\begin{tabular}{|l|l|l|l|l|l|l|l|l|l|l|l|l|}
\hline Eating unpasteurized cheese & $\mathrm{X}$ & $\mathrm{X}$ & & & & & & & & & & \\
\hline Food with high fat content & & $\mathrm{X}$ & & & & & & & & & & \\
\hline Food with high sugar content & & $\mathrm{X}$ & & & & & & & & & & \\
\hline Food with high salt content & & $\mathrm{X}$ & & & & & & & & & & \\
\hline Presence of pesticides & $\mathrm{X}$ & $\mathrm{X}$ & & & & & & & & & & \\
\hline $\begin{array}{l}\text { Long lists of ingredients with } \\
\text { additives }\end{array}$ & & $\mathrm{X}$ & & & & & & & & & & \\
\hline GMO & $\mathrm{X}$ & $\mathrm{X}$ & & & & & & & & & & \\
\hline Radioactivity & $\mathrm{X}$ & & & & & & & & & & & \\
\hline Mad cow disease & $\mathrm{X}$ & & & & & & & & & & & \\
\hline
\end{tabular}

B) Classic dishes

\begin{tabular}{|l|l|l|l|l|l|l|l|l|l|l|l|l|}
\hline Spontaneous mentions & & & & & & & & & & & & \\
\hline Spontaneous mentions & & & & & & & & & & & & \\
\hline Spontaneous mentions & & & & & & & & & & & & \\
\hline & & & & & & & & & & & & \\
\hline $\begin{array}{l}\text { Cassoulet (beans with } \\
\text { sausage) }\end{array}$ & & & & & & & & & & & & \\
\hline Choucroute (sauerkraut) & & & & & & & & & & & & \\
\hline Bœuf bourguignon (beef stew) & & & & & & & & & & & & \\
\hline Pot-au-feu (pot roast) & & & & & & & & & & & & \\
\hline Raclette (melted cheese) & & & & & & & & & & & & \\
\hline Pancakes & & & & & & & & & & & & \\
\hline Upside down apple tart & & & & & & & & & & & & \\
\hline Chocolate fondant & & & & & & & & & & & & \\
\hline
\end{tabular}

Table used for each respondent during the projective exercises 
ANNEXE A4 : Main verbatim comments by theme PERCEIVED NATURALNESS

\section{Ingredients criterion: suspicion regarding long complicated lists}

"You can see whether or not a product is low-end by looking at the number of additives there are in it. (...) In a quality [product], there will be almost no additives, and if there are ten additives, one of them corrects another, then another corrects that. It's industrial cooking, where they compensate for the poor quality of raw materials with flavor enhancers and things like that" (Jean-Marc).

"What I call a suspect product, is what I'm unable to identify, in good French. If I see a tomato soup contains (...) potatoes, tomatoes, carrots, then OK, I understood, salt, pepper, milk, mustard, lemon, OK. Once it's dextrose, modified starch, already there, well, I wonder why, then I understand why, they're thickeners, preservatives, and after that, there's E whatsits and A gizmos, and I don't buy it” (Marie).

"I tend to think that for something to be healthy, it should have as few ingredients as possible. (...) When it starts having a rather long list, there's the idea of something chemical behind it, processing, manufacturing, (...) I think it's industrial processing, and less based on taste and more on mass production, and profit. (...) Artisanal production is a guarantee of a better taste, yes, this is the image I have, it's more based on the product's nutritional qualities (...) compared to something industrial that is likely to be based, in my mind, on the economic returns from its manufacture (...) [I prefer to buy] the purest possible things and mix them myself" (Thierry).

\section{Processing criterion: advantages of home cooking}

"I'm more focused on simple products, not processed ones. When I look at the composition of processed products, I always find additives that not seem at all necessary for, uh, for cooking. (...) If I start from simple products, I believe I eat more healthily than if I take manufactured, processed products." (Sylvie).

"Ready made meals, I don't buy them. I don't know what's in them. I don't trust them, no. (...) I prefer to make it myself." (Maggy).

"I always wonder what's in pre-cooked dishes, I prefer to do it myself, it's best. I always think, what chemicals have they put in, I'm a bit psycho like that" (Audrey).

"Processed products, from a nutritional point of view, well there's nothing in them. (...) You're deceiving your body, and you're deceiving yourself about the goods [with] industrial products." (Laurence).

"I don't buy vitamin-supplemented milk. I figure that if I need vitamins, they are necessarily provided by the food that ought to provide me with them. If they're not in milk, it's because they shouldn't be in milk. If a fruit juice has added iron, I won't buy it. I prefer a normal fruit juice, with nothing added." (Marie).

"I think that prepared dishes I would buy, like lasagna or shepherd's pie, are worse than what I make myself, regarding taste and health (...) I'm convinced they're full of preservatives and things like that." (Adeline).

"I don't much like ready-made things. (...) At first, I hardly cooked at all, or things already prepared, but more and more I try either to cook myself or to eat something that's cooked by my parents." (Jan).

"A home-made cake, yes. (...) It's not an industrial cake, well, it doesn't come out of a factory. (...) It's better. Even for the health. Whereas an industrial cake, you don't know what they put in it. (...) Everything industrial, it's never good for one's health." (Lucie).

\section{Appearance criterion: rejection of standardized products that are too far from what is natural}

"Even fruit and vegetables, they all have the same shape, it's because they make them grow with products, phytosanitary products I think. (...) Real fruits, lemons, are dirty. (...) These lemons they are all alike, they all 
have chemicals in them." (Lucie).

"I don't mind if a carrot's ugly, for example. (...) Because I think it makes sense that nature produces (...) creative carrots. I think it's a shame they throw away small carrots because they're not the size the supermarket uses. I find that unacceptable. So what's from nature, plants, for me that's good."(Marie).

“A beautiful shiny product, properly graded and all, for me that doesn't necessarily mean quality, not at all. Rather it means standardization. So not necessarily a product produced to be good, but a product produced to look beautiful. Ultimately, it's suspect." (Claude).

\section{Criterion of time and place of production: respect for seasons, local preference}

"I still try to buy seasonal produce, and local produce." (Laurence).

"I look at where it comes from. Because that gives me an idea as to the season. If strawberries come from Chile, I don't buy them. I prefer not to eat them." (Marie).

“It's very important to follow the seasons. You have to respect the natural rhythm." (Claude).

“Each season, I have produce. I always have very fresh products. I don't eat out-of-season products. (...) A healthy diet is precisely eating seasonal vegetables. That is very important. That is to say, not eating tomatoes in winter, things like that" (Marie-Claude).

\section{Criterion of place of purchase: suspicion regarding mass retail and chain restaurants}

“As I've often heard, it's best to buy from a small retailer, and get his specialties to eat at home. (...) I prefer home cooking, I know what's in it, it's me who puts it there and I know where to find it." (Audrey).

“Take a butcher for example, you know you can trust his products (...), how he selects the raw materials and what he does with them. (...) When you see behind, in a supermarket, the butchers prepare the meat, it's good they're there, they do their eight hours, they work in a, let's say, industrial fashion. Whereas he does it with... you see him working with his apprentices, he does it with love, love of a profession done right." (Claude).

“When I go to my butcher's, I have this love of food side too, I want to buy everything in the shop. What's more, I know he has good beef (...). Whereas when I see meat in a supermarket, vacuum packed and... or even, they have butchers, I find that, I can walk around the meat section for three or four minutes and take nothing." (Laurence).

"In supermarkets, I get scared, I wonder whether it's going to be fresh, is it going to be good, , (...) especially with regard to the meat.. (...) For fruit, in the market, there's a little stall I like, (...) and I have a little North African grocer (...). I know him, so it's more reassuring. (...) In supermarkets, I don't much like the fruit, they always put a heap of stuff on it.” (Audrey).

“The chocolate fondant, for me that's a typical example of an industrial product in a restaurant. It means it's not good. It's really not good, either for its taste or for one's body (...). I used to naively think that all the dishes in a restaurant were made in the restaurant." (Marie).

"What scares me, is the nutritional value of the ingredients one eats, especially when one doesn't eat at home, (...) when you eat in a restaurant.” (Laurence). 


\section{APPENDIX A5 : Main verbatim comments by theme}

COMMENSALITY

\section{The reassuring role of traditional regional cooking, emblematic of sharing}

“Choucroute [sauerkraut], that's another dish for sharing, in winter, wonderful” (Marie).

"Raclette [melted cheese], that's something that typically I never eat alone, (...). You eat it in the evening after you've been in the fresh air during the day and you're with friends who like it and your have a friendly informal dinner together." (Thierry).

"For me, pot-au-feu [pot roast] is a winter dish, it warms you up. It's bad weather outside, you eat a good potau-feu. It's comforting.” (Claude).

“Tarte tatin [upside down apple pie] is a pleasure among friends or with one's family.” (Adeline).

“Ah, raclette's delicious. It makes one think of one's family. Generally it's for when my grandchildren visit.” (Madeleine).

"For me, they're dishes one eats with other people. Different generations, grandmother's dishes for children too." (Adeline).

"Cheese fondue, for me, it's somewhat the story of our family get-togethers, a traditional regional dish." (Thierry).

"The idea of a family meal. It's the type of meal that in some sense represents continuity, handing over." (Evelyne).

“Why not? Among pals, cooking a cassoulet [beans with sausages], that's it!” (Laurence).

“Regional products are something you share, yes. That one shares and wants to share.” (Hervé).

\section{In addition, the pleasure of sharing one's food}

"What counts is being together, and laughing, and sharing, talking about oneself, and the food is an excuse to stay together longer.” (Marie).

"It's not so much a question of what one eats, as the circumstances. For example, when I have friends who come to the house, I tend to cook them something that's not so different from what I eat myself, but the atmosphere is very different because of the general conviviality. (Thierry).

"It's the signature of France, eating well, yeah. I think it's best together, even. If you eat alone, it's not so great." (Hervé).

"You get food and fun, sharing a meal with friends, with family." (Sylvie).

"I say to myself, I'd enjoy myself having a meal with friends. Being able to go to a friend's, who's cooked a nice apple pie, I should say, it's fun, and what's more it's fun for the person who invites you, you're sharing with other people. But it shouldn't be something you do every day.” (Marie).

“Eating is a shared pleasure, and there's nothing better. Because it's a pleasure, it's moment of pleasure!" (Chantal).

"For sure, the canteen's not good (...). On the other hand, it places you in a team atmosphere, a sharing atmosphere. (...) The canteen is also a way to open oneself up to social life."(Marie).

"Inviting people is also the pleasure getting into the kitchen, that you don't do for yourself alone every day. For example, I like to cook cakes, well, I don't cook a cake for myself. I don't like doing that in fact. What I like is cooking a cake for people who come to visit. Or I'll bring it to work once in a while." (Thierry) 


\section{The guilt-alleviating aspect of commensality}

"Nutella is a fraud, it's amazing it's super good, but it's a disgusting product. (...) When you look at the list of ingredients, there's not even any chocolate in the stuff. (...) But you go away for a weekend with friends, and there has to be Nutella for the children, and you make yourself a good sandwich, you'll find Nutella delicious, and you'll be right to eat it. (...) All these treats are particularly tasty and enjoyable when you don't have them very often and they're shared with others. When they're eaten alone, or on poor quality products, (...) there's no longer any pleasure, no, and afterwards you feel guilty." (Marie).

"When you share, you can allow yourself to eat a lot, it's, it's not stressful. Whereas I think that if you're alone and you eat a lot, then you get stressed. When you share, you don't notice it. Even if you eat the same amount. (...) With several people, eating a lot, you feel less, uh... Eating well is sharing.” (Hervé).

"Meals with family or friends are not a source of stress. Whereas when I'm alone, well, all the time." (Lucie).

"When one's among friend or with the family, (...) it's normal to enjoy oneself. [Guilt] arises (...) when I come home in the evening during the week, I'm particularly hungry, I throw myself onto the food, then afterwards I say to myself, oh dear, I've eaten too much, it was stupid." (Adeline).

"I don't like eating alone. So, well, fairly automatically, it's when I'm watching something on TV. Which changes the state of mind you eat in. Then you tend to eat mechanically because you're more interested in what's happening on TV than in what you're eating." (Thierry). 


\section{APPENDIX A6: Main verbatim comments by theme}

\section{HYPERCHOIX}

\section{Choice is necessary to ensure nutritional variety}

"I think it's good for the health to eat in a balanced and varied way. (...) I need to have as many different foods as possible to give my body the maximum number of things.” (Adeline)

“ [My daughter] eats very badly. (...) But I fight. (...) But the more I do so, the more she eats badly from a nutritional point of view. (...) She'll eat alone, yeah, which she likes. Small amounts. But what she likes, is nonetheless bad from a nutritional point of view, it’s no good. (...) Nutella, pizza.” (Laurence)

“McDonald's is junk food because it's always the same, (...) not varied, not balanced.” (Adeline)

"With a varied diet, in general, you give your body what it needs, rather than taking supplements. Normally, if you eat enough fruit and vegetables, but also slow sugars, you'll have the intake you require. (...) If you don't have any health problems, (...) you shouldn't need to take supplements (Evelyne).

"If you eat in a balanced and varied way, you don't need to take nutraceuticals. Only if you have a deficiency in something.” (Adeline).

\section{Anxiety-producing choice}

"It's more something relative than absolute. That is to say, well, there are three different brands of tomato sauce on the shelves, and deciding among the three." (Thierry).

"The nutritionist said to me, (...) look at what there is in food. And that's why he encouraged me to go to health food stores, which I did, and even in a health food store, look, because it's not the fact of being organic he recommended, it was the content." (Marie).

"I look at the selection, and if there things that are fairly similar, and one of them is labeled organic or I see it looks, uh, less subject to this type of threat, I'll buy that one." (Adeline).

"Our worry is choosing (...) the right diet. Faced with an excess, it's being sure one's made the right choice. (...) Whereas previously, they didn't have diet worries, since there was no choice in fact, it's choice that gives rise to fear. (...) Previously, it wasn't coping with excess, if they gave one, um, chard, there wasn't any question as to how they'd grown it. (...) Our problem isn't eating, because we'll always have enough to eat, rather it's choosing, it's thinking that I hope I've eaten the right thing. (...). It's having a choice, in fact.” (Hervé)

"We [during the second world war] were so deprived that we were less particular perhaps than the new generation, who always have everything they want. Because we, as we were deprived, I think we are less... we look more to the satisfaction we get from eating rather than being too, how shall I put it?, not delicate, but... picky." (Madeleine).

\section{Restricting food choices at home}

"In our fridge, there are rarely very rich things in terms of calories.”(Hervé).

"I just have a box of cookies that I don't like, for if someone comes unexpectedly. (...) I'd eat them if I liked them. (...) I have to raise barriers for myself, not to have Nutella and stuff like that." (Marie).

“Adeline's rolling menus, that's fine. We have a more varied diet than previously. She does them over five-week periods, so for five weeks we have different things, then we begin again.” (Adeline's husband).

"I try to vary, white meat, red meat, fish, uh, it's more difficult, I tend to keep that for the weekend." (Adeline). 
"We never buy really discount prices, we avoid them. Well, at least until we've carefully looked at what's in them, but it's something we avoid." (Evelyne).

"Low-cost brands (...) are at the expense of quality. (...) That's what I learned [when I was a student], when one found things, like grated cheese that didn't have the right to be called cheese, it was the grated cheese specialty, because it couldn't be called grated cheese (laughter). Or sausage snacks that we remembered because the only way to eat them was to recall the price you'd paid for them, because otherwise you couldn't have (laughter)! So clearly, it was horrible, [both] in terms of taste and its nutritional value. (...) For example, the sausage snack, obviously, there was less meat and more fat than another sausage brand." (Thierry).

"I don't like spending too much time, I do my shopping on Télémarket in half an hour. (...) My criteria are not to buy down-market stuff, because I get the impressions it's not so good. (...) I always go for mid-range stuff in fact. (...)If it's low-cost, it's because they've really tried to lower all the prices, so they've necessarily (...) cut down on some criteria and that's got to be less good for one's health.. (...) this enables me to situate products, it's a scale." (Adeline).

"I say to myself: low price, inferior product, so it's something less than the basic product of a brand I'm familiar with." (Marie).

\section{Identifying indicators of extrinsic quality: brands and labels}

"For some products, in fact I'll always buy brands." (Laurence).

"A brand reassures me, if it's well known, yes, it reassures me." (Maggy).

"I situate myself mid-range, and afterwards I'll look at different brands, but there are some brands that, that I use more, out of habit, and that I like. So in any case I tend, if they have a product in that brand, to go for that brand. (...) For me the brand is more a reference point, I've already bought a brand, and so as a result I've liked it, and so I'll continue to buy the same product, or another product of the same brand." (Adeline).

"If I see Danone, I know that it's a serious company. But it's a bit like AB. I mean, I not going to get a nasty surprise with Danone (...) The plain yogurt I usually have in the fridge is a Danone yogurt. It's the only one I buy. I say to myself, it's a basic product, I trust a plain Danone yogurt. I'd say that's part of my upbringing. I don't imagine, uh, not trusting this brand that I've known for ever." (Marie).

"The brand doesn't necessarily influence me. No, the label counts more than the brand for me. Because an organic label is supposed to provide a product of equivalent quality irrespective of the brand." (Claude).

"Something that annoys me is organic everywhere you look, (...) every sauce, (...) to make them sell. You have to pay more to get the organic standard. And the results aren't guaranteed. (...) That's not to say that organic is bad, (...) but it's not necessarily a sign of great quality.. (...) I view it as an indicator and a source of information." (Sylvie).

"There's farm-bred chicken, there's free-range chicken, there's corn-fed chicken, it's a bit complicated." (Claude).

"I'll take the example of wine, the Appellation d'Origine Contrôlée, it's no way a guarantee of quality, oh no. So I don't believe at all in labels. No, you can buy, I don't know, say a Chambolle Musigny, vintage 2008, AOC, you buy ten, and out of the ten, there'll be two that are worth drinking and eight bad, all AOC. (...) It's not a guarantee, it's an additional filter." (Jean-Marc). 


\section{APPENDIX A7 : Main verbatim comments by theme PNR, BRANDS AND NUTRITION CLAIMS}

\section{Nutrition claims: information to be treated with caution}

“[Nutrition claims], I look at them, but I don't know whether I'm very responsive to them. Well, it depends on the information provided.. (...) It's difficult to know." (Sylvie).

"I find I can hardly read it. You've almost got to have a magnifying glass! And then well, it's true I don't really pay attention to it. (...) I'm not saying I definitely don't believe, but it's to be taken with a pinch of salt. There's exaggeration, you have to tone it down. But the claims aren't necessarily false or of no value." (Evelyne).

"If there's a brand with nothing added, then I'll check it, but it will attract my attention.. (...) Well, what makes me laugh, is when they say that Evian water is without added sugar. Sometimes they treat us rather like idiots. There've been things like that. There was flavored Volvic, without added sugar, well, I hope so. Or thirty times less sugar, things like that, that irritates me. But, er,... I check.” (Marie).

"Yes, well, there's everything that's said and is worthless: top-quality product, super, good for everyone, without any supporting evidence, so er (...), it's deception, it's advertising. But I look at what nevertheless has a certain established value. It mustn't just be advertising, they have to be confirmed claims!" » (Claude)

\section{Brands seen as nutritionally incompetent ${ }^{2}$}

"I don't believe them, (...) absolutely not. Because I think it's basically advertising, but there are no serious studies that have been conducted. To have serious studies done on the link between food and health, they have to cover thirty or forty years, minimum. We're far from having them." (Jean-Marc).

"Actimel, I don't at all believe [what they claim]. And yet I have an agriculturally trained daughter-in-law who works at Danone. So for us, Danone's just great, but I don't believe it." (Marie-Claude).

"I think it's a load of rubbish. Well, because in my opinion, what they put on the label is designed to make the customer choose that product. So firstly it's a message that ensures the product will be selected, and then, they try to... It has to some extent be based on truth, but... There's nothing proved, and the way it's phrased is always (...) rather ambiguous." (Adeline).

" $0 \%$ [fat] products, things like that, , (...) I don't necessarily pay attention to it, because I don't believe it. There's no need to eat vitamin-enriched things. Better to eat a good steak, that's full of vitamins!" (Audrey).

"Danone, (...) I know it's a, er, marketing message, and then, well, for me, they've rather surfed on this wave, and there's no guarantee of, well, they've not proved anything about it, in my opinion." (Adeline).

"Advertising, advertising, advertising! It's advertising, it's to sell [their products]. In my view, there's no effect on one's health. (...) You'd have to eat twenty yogurts a day for years, so all that is to induce sales, it's marketing." (Chantal).

\section{The accusation of lack of brand integrity}

"What Actimel claims, I don't believe it. I don't believe it at all. I think it's business, marketing. Anyway, they're not interested in feeding us well, these people. They're in business, (...) they have an image they want to promote, but they're not there to do us good, , (...) they're there to grow their sales." (Laurence).

"In the end you raise questions. (...) There are no limits. They can be dishonest also regarding the ingredients,

\footnotetext{
${ }^{2}$ Competence and integrity are the two dimensions of credibility (Simon et al., 1970)
} 
they can sell poor quality products to make a profit from the business." (Claude).

"For example, high in omega 3, all that, I pay no attention to it. Because I don't believe in it, no, not at all. (...) On the packaging of food products, (...) manufacturers take advantage of it and don't list all the ingredients they've put in, in fact." (Jérémy).

"I prefer not to look at the ingredients any longer, because anyway, not all the contents are, er, wholesome." (Lucie).

"I tell myself, Danone cannot (...) make a mistake in what they put into their products, because they're closely monitored, it's an enormous group, there's too much at stake. But I'm not fooled, y'know.” (Marie)

"All the ingredients shown on the back of products are what they want to show us. And so most of the time, when they put $0 \%$ fat, it's misleading advertising, because, well, it's replaced by synthetic fat or things like that. And they're not necessarily good for the health, either." (Jérémy).

"I'm aware we live in a world of business and marketing. I try not to let it get the better of me. I mean, when it comes to nutrition, I know about it, I want to resist, and I just can't do it. it's just really frustrating." (Marie).

\section{Notes}

${ }^{1}$ European Regulation No 1924/2006 defines a claim as "any message or representation, which is not mandatory under Community or national legislation, including pictorial, graphic or symbolic representation, in any form, which states, suggests or implies that a food has particular characteristics" (Art. 2.2.1); for a food claim, it is "any claim which states, suggests or implies that a food has particular beneficial nutritional properties due to (a) the energy (calorific value) it (a) the energy (calorific value) it (i) provides, (ii) provides at a reduced or increased rate, or (iii) does not provide; and/or (b) the nutrients or other substances it (i) contains, (ii) contains in reduced or increased proportions, or (iii) does not contain; (i) provides, (ii) provides at a reduced or increased rate, or (iii) does not provide; and/or (b) the nutrients or other substances it (i) contains, (ii) contains in reduced or increased proportions, or (iii) does not contain" (Art. 2.2.4); and for a health claim, it is "any claim that states, suggests or implies that a relationship exists between a food category, a food or one of its constituents and health" (Art. 2.2.5).

${ }^{2}$ NB: Actimel changed its claims in 2010 in accordance with European Regulation EC1924/2006.

${ }^{3}$ From May to July 2012: E. coli in Germany due to germinated organic seeds, attributed at first to Spanish cucumber (29 occurrences among the respondents); then E. coli in France due to spoiled hamburger steaks.

${ }^{4}$ http://www.foodmanufacture.co.uk/Ingredients/Top-12-trends-for-food-nutrition-and-health, appearing on 18 December 2013 